\title{
The Chinese Jamaican Oral History Project
}

\author{
by \\ Daniel Clarkson Fisher \\ Doctorate in Buddhist Studies, University of the West, 2013 \\ Master of Divinity, Naropa University, 2006 \\ Bachelor of Arts, Denison University, 2001 \\ A Major Research Paper \\ presented to Ryerson University \\ in partial fulfillment of the \\ requirements of the degree of \\ Master of Fine Arts \\ in the program of \\ Documentary Media
}

Toronto, Ontario, Canada, 2019

(C) Daniel Clarkson Fisher, 2019 


\begin{abstract}
Author's Declaration
I hereby declare that I am the sole author of this thesis. This is a true copy of the thesis, including any required final revisions, as accepted by my examiners.

I authorize Ryerson University to lend this thesis to other institutions or individuals for the purpose of scholarly research.

I further authorize Ryerson University to reproduce this thesis by photocopying or by other means, in total or in part, at the request of other institutions or individuals for the purpose of scholarly research.
\end{abstract}

I understand that my thesis may be made electronically available to the public. 


\begin{abstract}
The Chinese Jamaican Oral History Project is an initiative that aims to record and preserve memories and stories from the Chinese Jamaican community in Toronto. Its two distinct components are: (1) an online archive of audio-recorded oral history interviews, narrator portraits, and other images; and (2) an exhibition made from the contents of that archive. Specifically, the exhibition is comprised of twelve digital stories -- one for each of the narrators who has participated in the project so far. In every case, a soundbite has been selected to represent the complete oral history interview (which is archived online in full). Together with the images, these voices tell a story of the Chinese Jamaican community in Toronto, while also underscoring the diverse range of individual experiences within it.
\end{abstract}




\section{Acknowledgments}

There is no oral history project without its narrators, so I must first thank those who collaborated with me to inaugurate the Chinese Jamaican Oral History Project: Brian Chang, Suzanne Kong, Patrick A. Lee, Dr. Anne-Marie Lee-Loy, Dr. Keith D. Lowe, Eustace Lyn, Joan Lyn, Stephanie Lyn, Kay Moosie, Jenna Tenn-Yuk, Carol Williams-Wong, and Tony Wong.

If this project had not been made in the spirit of shared authority, first thanks would certainly have been reserved for my primary supervisor, the brilliant Dr. Blake Fitzpatrick. Blake improved every aspect of this project, every step of the way, with his constructive questions, thoughtful observations, and insightful suggestions. If this all came out much better than I expected, a tremendous lot of that has to do with him.

My advisor, Dr. Bruno Lessard, has been similarly encouraging and supportive since our first meeting. In particular, his regular check-ins and other benevolent acts were greatly appreciated at busier and more trying points during the course of my studies.

I am also indebted to my other wonderful professors in the Doc Media program, but especially Dr. Gerda Cammaer, Sara Angelucci, Vid Ingelevics, Dr. Brett Story, Marc Glassman, and Michèle Pearson Clarke. Each directly and/or indirectly influenced the development of this project in very significant ways as well.

In addition, I was ridiculously fortunate to receive feedback on the work-in-progress from Richard Fung during his visit to our Master Class. The project in its present state owes much to his knowing advice, and I cannot thank him enough for being so generous with his critique.

My cohort in the program deserves a lot of credit here too. I am loath to single out individuals -- I truly feel like every one of my classmates has been helpful to me and to the project in important ways -- but my dear friend Tara Korkmaz deserves special praise for her 
peerless leadership of the 2019 DocNow Festival. Her hard work made for the perfect project launch, and I know I'm not the only one among my classmates who can say that.

Of course, I thank my family, including and especially my Chinese Jamaican family, for all their many kindnesses over the last two years.

I also gratefully acknowledge the financial support of the Social Sciences and Humanities Research Council, the Ryerson Faculty Association, and the Yeates School of Graduate Studies.

The Chinese Jamaican Oral History Project began with the vision of the late, great photographer Ray Chen. For pointing the way forward, I thank both him and the members of the working group that he assembled back in 2015: they include Jeanette Kong, Roger Chen, Robert Hew, Loraine Lee, and Jennifer Chin, as well as Patrick, Anne-Marie, Carol, and Stephanie.

Stephanie is also my partner in life, and was my gateway into documenting the Chinese Jamaican community; I "married into" this project, as it were. I love her with all of my heart, and could not have completed this program (financially or otherwise) without her or her faith in me. As such, I dedicate all of my work on the Chinese Jamaican Oral History Project to Stephanie. 


\section{Table of Contents}

Author's Declaration ii.

Abstract iii.

Acknowledgements iv.

Table of Contents vi.

Epigraph vii.

$\begin{array}{ll}\text { Introduction } & 1\end{array}$

$\begin{array}{ll}\text { Chapter 1: Project Content } & 6\end{array}$

$\begin{array}{ll}\text { i. The Basics } & 6\end{array}$

ii. Family Matters and Positionality $\quad 8$

iii. A Tradition of "Moving Stories" 10

$\begin{array}{ll}\text { Chapter 2: Methodology } & 16\end{array}$

$\begin{array}{ll}\text { i. Beginnings } & 16\end{array}$

ii. Stops and Starts $\quad 19$

iii. Research $\quad 22$

iv. Oral Histories and Portraits 24

v. Website $\quad 26$

vi. Exhibition 29

Chapter 3: Documentary Relevance 33

i. Oral History as Documentary Mode and Medium 33

ii. "Thick Vision” in Digital Storytelling 39

Conclusion: From Cross-Cultural to Community Oral History Project 44

$\begin{array}{ll}\text { Appendices } & 46\end{array}$

Bibliography $\quad 53$ 
"I've been searching for a genre that would be most adequate to my vision of the world to convey how my ear hears and my eyes see life. I tried this and that and finally I chose a genre where human voices speak for themselves."

- Svetlana Alexievich, author of Voices from Chernobyl: The Oral History of a Nuclear Disaster and recipient of the 2015 Nobel Prize in Literature ${ }^{1}$

“...I hope that memory is valued -- that we do not lose memory."

- Studs Terkel, author of "The Good War": An Oral History of World War II (winner of the 1985 Pulitzer Prize for General Nonfiction) ${ }^{2}$

\footnotetext{
${ }^{1}$ Svetlana Alexievich, "A Search for Eternal Man: In Lieu of Biography," accessed March 15, 2019, http://alexievich.info/en/.

2 Religion \& Ethics Newsweekly, "Interview: Studs Terkel," last modified December 19, 2003, https://www.pbs.org/wnet/religionandethics/2003/12/19/december-19-2003-interview-studs-terkel/11022/.
} 


\section{Introduction}

During the 1970s, thousands of Chinese Jamaicans -- including my partner Stephanie, her parents, and her maternal grandmother -- immigrated to North America. They were descendants of the indentured Chinese labourers brought to Jamaica in the nineteenth century, the free immigrants who later came to join them, and the racially-mixed families created on the island. Some were fleeing flare-ups in ethnic and political violence, while others felt uncertain about their future under then-Prime Minister Michael Manley’s democratic socialist government. Others still were simply taking advantage of new opportunities abroad. The largest group settled in the Greater Toronto Area, ${ }^{1}$ and the community has had a marked effect on the city since arriving. ${ }^{2}$ The late business magnate G. Raymond Chang, Ryerson University's third chancellor and the namesake of its School of Continuing Education, for example, was Chinese Jamaican.

But despite the uniqueness of this close-knit and unassuming immigrant community, and the considerable impact it has had, only limited work has been done in terms of recording Chinese Jamaican oral histories -- both in Canada and in general. ${ }^{3}$ This major research project

\footnotetext{
${ }^{1}$ By way of explanation, M. Labelle, Serge Larose, V. Piché, and Channon Oyeniran note in their entry "Caribbean Canadians" (https://www.thecanadianencyclopedia.ca/en/article/caribbean-canadians) for the Canadian Encyclopedia (last edited May 3, 2019) that "of the 749,155 Canadians reported to have Caribbean origins in the 2016 census, the vast majority immigrated to Canada after the multiculturalism policy was initiated in 1971 by then-prime minister Pierre Elliott Trudeau."

${ }^{2}$ I use the term "community" throughout this support paper in the same ways that Linda Shopes speaks about it in her article "Oral History and the Study of Communities: Problems, Paradoxes, and Possibilities" for the Journal of American History 89, no. 2 (2002): "A community oral history project typically refers to one defined by locale, to a group of interviews with people who live in some geographically bounded place, whether an urban ethnic neighborhood, a southern mill village, or a region of midwestern farms. Yet 'community' also refers to a shared social identity, and so we speak of interviews with members of the gay community, the black community, the medical community. In fact, many community oral history projects combine the two meanings of the term, focusing on a particular group's experience in a particular place -- steelworkers in Buffalo, Chicanos in El Paso, jazz musicians in Los Angeles" (588).

${ }^{3}$ Books and articles featuring selected testimonies, memories, and stories from Chinese Jamaicans include Ray Chen's The Shopkeepers: Commemorating 150 Years of the Chinese in Jamaica, 1854-2004: A Historical Record of Their Arrival and Personal Stories of Their Endeavours and Experiences (Markham, ON: Periwinkle Publishers Inc., 2005); Patrick A. Lee's Canadian Jamaican Chinese, 2000: A Pictorial History of Jamaican Chinese Families Spanning Five Generations
} 
(MRP), titled the Chinese Jamaican Oral History Project, contributes to efforts at rectifying this with two creations. The first is an online archive (CJOHP.org) comprised of twelve long-form, audio-recorded oral histories; portraits of each narrator; and any images and/or documents submitted by the narrators. The second is a public exhibition of twelve "digital stories" (one for each narrator) made up of selections from the archive. ${ }^{4}$ Weaving these audiovisual materials together online and in the exhibition, this project tells the story of the Chinese Jamaican community in Toronto, while also underscoring the wide range of their individual experiences. ${ }^{5}$ Before going further, it must be said that I am approaching this subject as an outsider: a

(Scarborough, ON: Huntsmill Graphics Ltd., 2000) and Jamaican Chinese Worldwide - One Family (Scarborough, ON: Huntsmill Graphics Ltd., 2004); Walton Look Lai's The Chinese in the West Indies, 1806-1995: A Documentary History (Kingston, Jamaica: The Press University of the West Indies, 1998); David Katz's Solid Foundation: An Oral History of Reggae (Minneapolis, MN: Jawbone Press, 2012); and M. Alexandra Lee's article "They Never Looked Back: The Role of Hakka Women in Jamaica" for Caribbean Quarterly 50, no. 2 (2004). The documentary films of Jeanette Kong -- The Chiney Shop (2012), Half: The Story of a Chinese-Jamaican Son (2013), and Finding Samuel Lowe: From Harlem to China (2014) -- are also built around stories and memories she has gathered from within the community. Additionally, in her article "Unfinished Synthesis: Georg Simmel's Adventure, Two Chinese Jamaican Migration Narratives, and the Negotiation of Modern Identity" for Caribbean Studies 38, no. 2 (2010), project narrator Dr. Anne-Marie Lee-Loy mentions that Chinese Jamaicans who were sent to China as children in order to be "raised and educated" were interviewed during the summer of 2005 at the Tsung Tsin Association of Ontario in what "essentially [amounted to] an oral history project" (51).

${ }^{4}$ In her book Practicing Oral History with Immigrant Narrators (New York: Routledge, 2015), Carol McKirdy defines a digital story as "a first-person narrative...made into a mini movie...using new media and digital video technology." It typically "[lasts] for two to three minutes" and includes "a mixture of digital graphics, text, recorded audio narration which publishes as voiceover, video and or photographs, and [sometimes] music and/or sound effects" (103).

${ }^{5}$ Those familiar with the concept of "transnationalism" -- defined by Linda Basch, Nina Glick Schiller, and Cristina Szanton Blanc in their book Nations Unbound: Transnational Projects, Postcolonial Predicaments and Deterritorialized Nation-States (New York: Routledge, 1993) as "a process by which migrants, through their daily life activities create social fields that cross national boundaries" -- might have an overarching question about the project's approach (22). Specifically, does the MRP reify outmoded ideas about the importance of the nation-state in its focus on quote unquote "Chinese Jamaicans"? By way of a response, I would simply say that I am compelled by project narrator Dr. Anne-Marie Lee-Loy's qualified response to the concept in her book Searching for Mr. Chin: Constructions of Nation and the Chinese in West Indian Literature (Philadelphia: Temple University Press, 2010). “...Whether or not the nation-state exists today in the form in which it was understood in the early twentieth century, the relationships between individuals within (former) nation-states have long-term implications," she writes. "In the same way that the implications of colonialism are still being felt long after the colonies ceased to exist as political units, the relationships between Chinese and other West Indians that were founded when the concept of the nation was more secure do not just disappear even if the idea of nation itself has changed" (4). And indeed, the oral histories that make up this MRP attest to both the reality of transnationalism and Dr. Lee-Loy's contributions to the discourse about it. 
White settler who has married into the Chinese Jamaican community, but is not of it. Among other things, this fact places my work into the category of "cross-cultural interviewing" -- or, what William Schneider defines as that which "[involves] an interviewer and an interviewee who come from different backgrounds and have different experiences." ${ }^{\circ}$ On the one hand, this approach comes with some built-in possibilities for doing good work. For example, as Schneider notes, competently conducting any cross-cultural interview requires research and preparation above and beyond the usual groundwork, thereby "[making the interviewer all the] more conscious of the role of context and how circumstances affect construction of narrative." ${ }^{\circ 7}$ On the other hand, though, there are also issues of power and privilege to contend with in cross-cultural interviewing, particularly when the narrators are people of color who have historically suffered under colonialism and the interviewer/researcher is a White settler.

That said, my own "goals as a White researcher" are the same as Jan L. Peterson's: "doing research that stands witness to the voices and stories of every day [sic] people previously silenced by White traditions in research and [countering] the bias of and my place in dominant paradigms." ${ }^{8}$ To do this, she argues, one must develop "a positive White racial identity." ${ }^{9}$ Here Peterson borrows from the work of research psychologist Janet E. Helms, explaining that, "according to White identity theory, the process of developing a positive White racial identity requires White researchers to engage in two critical steps of reflection: (a) accept and examine the meaning of Whiteness, White racial identity, and inherent biases and privileges

\footnotetext{
${ }^{6}$ William Schneider, "Interviewing in Cross-Cultural Settings," in The Oxford Handbook of Oral History, ed. Donald A. Ritchie (New York: Oxford University Press, 2011), 51.

${ }^{7}$ Ibid., 62.

${ }^{8}$ Jan L. Peterson, "The Intersection of Oral History and the Role of White Researchers in Cross-Cultural Contexts," Educational Foundations 22, nos. 3-4 (2008): 50.

${ }^{9}$ Ibid., 46.
} 
attached to this identity and (b) acknowledge the meaning of being White in sociopolitical contexts that oppress people not in the dominant group." ${ }^{10}$ Specifically, this involves recognizing that "White people are not [always] aware they have a racial identity, [though they might at the same time] easily identify others as people of color." ${ }^{11}$ In addition:

Whites [also] have unearned benefits from being White; specifically, Whites have the power and luxury to ignore issues of race and to conclude that racism is a nonentity, while at the same time enjoying privileges associated with Whiteness without scrutiny. ...They can discount the accounts of racism by people of color or pretend they do not see the inequities. ${ }^{12}$

This support paper will, in part, discuss the strategies that have come from my efforts to cultivate a positive White racial identity. At the outset, though, it bears mentioning that I believe doing oral history is a principal strategy in and of itself. Although no methodology is perfect, oral history, whether cross-cultural or intracultural, gives narrators the opportunity to describe their own experiences in their own words -- and at length, if necessary. I share with other practitioners the belief that this has great value in several regards. Writing about oral history's place in African American studies, for example, Albert S. Broussard notes: "In spite of the vagaries of memory and the impact of race and class differences between interviewers and [narrators] in obtaining accurate testimonies, oral history has provided a richer, more complex, and more complete picture of the African American past." ${ }^{13}$ Peterson also observes:

Racism, inequities, and oppression are brutal, ugly, and cruel and the effects on human life cannot be dressed up, intellectualized, or simply shoved into numerical measurement. Lived experiences are real and to minimize the feelings, emotions, and memories of the

\footnotetext{
${ }^{10} \mathrm{lbid}$.

11 lbid., 35.

12 Ibid., 46.

${ }^{13}$ Albert S. Broussard, "Race and Oral History," in The Oxford Handbook of Oral History, ed. Donald A. Ritchie (New York: Oxford University Press, 2011), 199.
} 
people is a travesty. Oral history is one approach in which the stories of people previously ignored in the accounts in history are told, reflecting real human conditions. ${ }^{14}$ The Chinese Jamaican Oral History Project is deeply informed by these and other insights about oral history's myriad possibilities in terms of documenting historically marginalized communities. Especially when it is done with integrity and the procedures for accountability that scholars like Peterson delineate, I believe oral history can be an incredibly powerful methodology -- and not only for social scientists, but documentary media-makers as well.

${ }^{14}$ Peterson, 50. 


\section{Chapter 1: Project Content}

\section{The Basics}

If they fit into any preexisting area of oral historical work, the interviews that make up the Chinese Jamaican Oral History Project are most definitely examples of what Alistair Thomson calls "moving stories" -- or, oral histories "[centered] on the physical experience of movement between places." ${ }^{15}$ Collectively, the narrators' stories span not only Jamaica and Canada, but China and other parts of the world as well. Moreover, even for those narrators who have not experienced migration(s) themselves, their families' movements nonetheless loom large in both their interviews and lives. ${ }^{16}$ And while there are many similarities that can be appreciated in aggregate, the individual oral histories that comprise this MRP also illustrate the considerable diversity of experience and opinion within the community. ${ }^{17}$

The representative sample of twelve narrators that I have selected for the launch of the Chinese Jamaican Oral History Project (some of them mentioned above) includes:

- Brian Chang, Campaigns Organizer at the Public Service Alliance of Canada (PSAC); former Campaigns Officer for the Ontario Public Service Employees Union (OPSEU); former political organizer for Olivia Chow, Jagmeet Singh, and

\footnotetext{
${ }^{15}$ Alistair Thomson, "Moving Stories: Oral History and Migration Studies," Oral History 27, no. 4 (1999): 36, accessed March 15, 2019, https://www.jstor.org/stable/40179591.

${ }^{16}$ It would certainly not be overstating things to say that the full story of the Chinese Jamaican community deserves a thorough, nuanced, and minimally dissertation-length telling. In lieu of that, a quick-and-dirty "brief history" would suffice. Unfortunately, however, space in this support paper is limited, and there is room in it for neither. Fortunately, though, whatever thoroughness, nuance, and length we have on offer can be found in the MRP itself. In particular, the interactive timeline was created expressly for the purpose of providing historical context: https://cjohp.org/timeline.

${ }^{17}$ As Linda Shopes puts it in her article "Oral History and the Study of Communities: Problems, Paradoxes, and Possibilities" for the Journal of American History 89, no. 2 (2002): "Only slowly do underlying strands of a community's culture reveal themselves, as interview after interview sounds the same themes; only occasionally does an interview provide a flash of insight that enables us to read the culture outward and make connections with broader historical concerns. ... Any given interview can offer specific details and colorful anecdotes for a community study; a body of interviews, thoughtfully considered, can open up an understanding of the local culture, those underlying beliefs and habits of mind, those artifacts of memory that propel individual lives, give coherence to individual stories, and perhaps extend outward to a larger significance" (593; 588).
} 
Jennifer Keesmaat; 2019 New Democratic Party (NDP) Candidate for Toronto Centre's Member of Parliament; writer

- Suzanne Kong, IT professional, survivor of anti-NMDA receptor encephalitis (first diagnosed case in Canada)

- Patrick A. Lee, retired typesetter, community historian, and author

- Dr. Anne-Marie Lee-Loy, Associate Professor of English at Ryerson University

- Dr. Keith D. Lowe, multicultural studies scholar, consultant, former director of the Chinese Cultural Centre of Greater Toronto, former president of the Ontario Multicultural Association, co-chair of the Toronto Hakka Conference

- Eustace Lyn, retired hardware store owner (also: my father-in-law)

- Joan Lyn, retired hardware store owner, 1971 and 1972 Jamaican National Badminton Champion (women's doubles, with Jennifer Haddad) (also: my mother-in-law)

- Stephanie Lyn, Director of Quality Management at CI Financial (also: my partner)

- Kay Moosie, retired administrative assistant, one of the first steering committee members for the Chinese Caribbean Association (also: Stephanie's aunt)

- Jenna Tenn-Yuk, writer, speaker, facilitator, performer, and LGBTQIA+ activist

- Carol Williams-Wong, author and past president of the Tsung Tsin (Hakka) Association of Ontario

- Tony Wong, television critic for the Toronto Star

The interviews range in length from just over fifteen minutes to nearly two hours. In them, narrators share biographical information, memories, descriptions of work and family, stories of migration (if applicable), reflections about the Chinese Jamaican community, and thoughts about their relationship to it. The accompanying still portraits shows each narrator in a setting where they work, recreate, or commute. (Some images have been slightly posed, and others not at all.) Additionally, as mentioned above, if the narrator has chosen to share any family photos or other archival materials, scans of those are included with their interview audio and portrait online. The website also includes, among other things, an extensive "Resources" pages (with recommended readings, links, and so on); an interactive timeline; and social media accounts. For all intents and purposes, though, the oral histories are the main content of this project. 


\section{ii. Family Matters and Positionality}

Before talking about the content of these interviews, I should address the fact that, as noted above, a few of these narrators are immediate or extended family members. While this might disconcert traditional social scientists, such inclusions are not abnormal in oral history work. In fact, as no less than Donald A. Ritchie points out, "Researchers are increasingly interested in the lives of everyday people and open to looking at family oral histories for valuable information." 18 Of course, as Thomson and Robert Perks further note, while the "value" of such interviewing "is not in doubt," there are "the complexities of the family context [that] need careful evaluation and even more caution when it comes to sharing and reusing the data."19 Among the resources they recommend is Valerie Raleigh Yow's Recording Oral History: A Guide for the Humanities and Social Sciences, which devotes an entire chapter to family research. ${ }^{20}$ While her guidelines mostly amount to balancing common-sense thoughtfulness with academic rigor, I take as an article of faith her assertion that "family history, thoroughly researched, that confronts and deals with serious concerns, presents an honest account, and places the individual family in a wider historical context can be enlightening." ${ }^{21}$ And, when all is said and done, I feel that these interviews show what anthropologist Oscar Lewis believes can be shown by putting conscientiously-produced family interviews side-by-side: as Yow puts it, "real individuals as they live and work together in their family group rather than...averages or

\footnotetext{
${ }^{18}$ Donald A. Ritchie, Doing Oral History, Third Edition (New York: Oxford University Press, 2015), 254.

${ }^{19}$ Robert Perks and Alistair Thomson, "Interviewing," in The Oral History Reader, Third Edition, eds. Robert Perks and Alistair Thomson (New York: Routledge, 2016), 139.

${ }^{20}$ Ibid., 145.

${ }^{21}$ Valerie Raleigh Yow, Recording Oral History: A Guide for the Humanities and Social Sciences, Second Edition (Walnut Creek, CA: AltaMira Press, 2005), 254.
} 
stereotypes out of context." ${ }^{22}$ Together, my family and I have certainly endeavoured to produce useful interviews, as opposed to what Yow calls "laudatory accounts, skimming the surface of serious issues, masking the unpleasant events, whitewashing the less-than-respectable deeds."23 Including family interviews in the project also does something else for it that is key: it signifies my own positionality (or, "where one stands in relation to "the other"'). ${ }^{24}$ As mentioned above, I am an outsider in the sense that I am not of the community -- but I am in it by virtue of being married to Stephanie. As such, my exploration of her family and their community is, as Yow writes, not just "a journey into [their] past, but...also an exploration of [myself]--of the stories, rituals, relationships, and values that [have come to] influence [my] own way of looking at the world." Furthermore, "the process itself of going over a life together is a means of coming to understand family members and drawing closer to them. ${ }^{.25}$ The family interviews, then, go a long way towards speaking to "where I stand in relation to" the Chinese Jamaican community.

Yow's insights here will no doubt be familiar to those in documentary studies: in his influential work on "domestic ethnography" -- or, "a mode of autobiographical practice that couples self-interrogation with ethnography's concern for the documentation of the lives of others" -- Michael Renov has noted how, "due to kinship ties, subject and object are bound up in one another. ${ }^{26}$ But oral history projects, by and large, are also distinct from domestic ethnographies in important respects. In the case of this MRP, for instance, while my own positionality is clearly acknowledged and necessarily included, it is not primarily a work of

\footnotetext{
${ }^{22}$ Ibid., 274.

${ }^{23}$ Ibid., 254.

${ }^{24}$ Sharan B. Merriam, Juanita Johnson-Bailey, Ming-Yeh Lee, Youngwha Kee, Gabo Ntseane, and Mazanah Muhamad, "Power and Positionality: Negotiating Insider/Outsider Status Within and Across Cultures," International Journal of Lifelong Education 20, no. 5 (2001): 411.

${ }^{25}$ Yow, 273.

${ }^{26}$ Michael Renov, The Subject of Documentary (Minneapolis: University of Minnesota Press, 2004), 44.
} 
"autobiographical practice," nor should it be. Obviously, as a practitioner of oral history, I find some truth in Renov's notion that "if it tells us about cultures and societies, as [Johannes] Fabian claims all ethnography must, it does so only in miniature.” But I would also reject any implication that putting oneself front-and-center is the only way to demonstrate that one has "[abandoned]" all "pretense to authoritative or generalizable knowledge of the one for the other"; I am satisfied that participating in oral history, which takes as foundational the notion of "intersubjectivity, ${ }^{, 27}$ is demonstration enough that I have abandoned any such pretense. ${ }^{28}$ What's more, I think that for me as a White settler to use my Chinese Jamaican family to "serve as a mirror or foil for the self" would be unseemly and exploitative, not to mention a show of obliviousness to the realities that inform a positive White racial identity. ${ }^{29}$

\section{iii. A Tradition of "Moving Stories"}

All this in mind, the oral history interviews that make up this project's content, then, are best described as "moving stories." And, indeed, they feature many of the hallmarks Thomson lays out. For example, because the narrators are individuals in the fullest sense of the word, the

\footnotetext{
${ }^{27}$ In Oral History Theory (New York: Routledge, 2010), Lynn Abrams defines "intersubjectivity" as it is traditionally understood within the field: "The oral history document created in the interview is the result of a three-way dialogue: the respondent with him or herself, between the interviewer and the respondent and between the respondent and cultural discourses of the present and the past. This means that individual memory stories are shaped (not determined) by the intersubjective relationships present in the interview and that what we researchers hear are narrative reconstructions of memories of experiences actively created for an audience. The story that is told is thus a partial one, or at least a version of the past created with a specific context and for a specific purpose." She also notes that "two further theoretical concepts developed by oral historians arise from [the] understandings about" intersubjectivity: "The first is the idea of the cultural circuit which refers to the process by which personal memories of events and public representations of events inform one another. The second is the concept of composure. This refers to the striving on the part of the interviewee for a version of the self that sits comfortably within the social world, an account that achieves coherence or 'subject composure'" (59).

${ }^{28}$ Michael Renov, "Domestic Ethnography and the Construction of the 'Other' Self," in Collecting Visable Evidence, edited by Michael Renov and Jane M. Gaines (Minneapolis: University of Minnesota Press, 1999), 153.

${ }^{29}$ Renov, The Subject of Documentary, 44.
} 
project, taken as a whole, underscores "how the 'subjectivity' -- knowledge, feelings, fantasies, hopes and dreams -- of individuals, families and communities informs and shapes the migration experience at every stage and is in turn transformed by that experience." ${ }^{\prime 30}$ In addition, because this MRP is audio-centered, the narrators' "emphases and silences, linguistic patterns and metaphors" can literally be heard and are that much more "richly revealing about the nature and meaning of migrant experience" than they would be in transcript form. ${ }^{31}$

Getting down to the nitty-gritty, though, the interviews also "[reveal] the complex weave of factors and influences [that have contributed] to migration and the processes of information exchange and negotiation with families and social networks." 32 While the narrators who experienced migration from Jamaica to Canada generally point to the same reasons for leaving the island, some emphasize particular "factors and influences" over others. Kay, for example, talks mostly about the Manley government, while Keith focuses more on how he felt things had changed in terms of personal safety -- specifically, he recounts the harrowing experience of being mugged during an excursion with his wife. The stories of how these narrators made their way to Canada (what their "processes" looked like) vary interestingly as well. Eustace and Carol's interviews, for example, offer lots of rich details about their respective movements, with notable contrasts in terms of their class positions. In addition, every interview shows how "social networks," especially extended family, are "a crucial aspect of the migration experience." 33 One especially dramatic example here is Tony: as a pre-teen, he was sent to Toronto to live with extended family years ahead of his parents' migration to Canada.

${ }^{30}$ Thomson, "Moving Stories," 29.

31 lbid., 34.

32 lbid., 28.

${ }^{33}$ Ibid. 
"Moving stories" also "recall the cultural life of migrant communities," Thomson notes. Though Chinese Jamaicans actively continue their cultural life in Toronto -- in obvious recognition of "the importance of familiar cultural practices for the sustenance of migrant identity and community" -- the interviews with Patrick, Eustace, Joan, Keith, Kay, and Carol feature many salient memories about ways of life on the island as well. Throughout their stories, all of these narrators "[illuminate] the complex interplay between introduced, minority cultures and the dominant practices of the host society." ${ }^{34}$ For instance, Carol, whose thoroughly acculturated family screened movies in their shop, talks about longing to visit China while watching the films of Hollywood star Nancy Kwan. Conversely, Patrick describes an atypical shopkeeping experience serving a mostly Chinese clientele, and not getting to know Black Jamaicans as well as Eustace. And Eustace, who was one of the children sent away to China for education, often speaks poignantly to this "complex interplay" in his life. While narrators who have spent little or no time living in Jamaica have interesting things to say on this front as well, Jenna's contributions here are particularly noteworthy: during her interview, she recites her poem "Everyone Loves a Jamasian Girl," which speaks in part to the frustration of not fitting neatly into the categories "Chinese," "Jamaican," or "Canadian."

Because seven of the twelve narrators are women, I think the project also "[highlights] the particular experiences of women migrants and the gendered nature of the migration experience." That said, every interview in some way manages to convey how "migrant women have often played critical roles in ethnic community development": Jamaican families tend toward the matriarchal, and Chinese Jamaican families are no exception. ${ }^{35}$ This is perhaps

\footnotetext{
34 Ibid., 29.
}

${ }^{35} \mathrm{lbid}$. 
clearest in Stephanie's interview, in which she remembers her maternal grandmother Marie Moosie (1916-2015) as the one who managed the household and family affairs. In addition, Brian and Suzanne's discussions about Chinese Jamaican food quickly become loving tributes to their mothers -- as both cooks and flamekeepers. Elsewhere, the octogenarian Keith remembers how Jamaica's matriarchal culture sometimes clashed with the patriarchal aspects of Chinese culture in his own family growing up, leading to tensions with his sisters. Carol talks about her alternately playful and derisive nickname, "The Dragon Lady," as well. The moniker, which invokes a negative stereotype about East Asian women, seems to be meant to mock her Type A personality, high profile, and industriousness on behalf of the community. ${ }^{36}$ Kay's daughter, Tracey Chang, also interrupts the interview to explain that her mother is too humble to tell me something: that the Chinese Caribbean Association effectively began with a meeting hosted by Kay in the family's basement. ${ }^{37}$

Some interviews also "help us understand how collective motifs and myths might be resonant and meaningful" for many in the community. ${ }^{38}$ Keith, for instance, has been deeply affected by learning about his Hakka ancestors, and clearly draws inspiration from their experiences throughout history; his interview is exemplary in this regard. At the same time, other

\footnotetext{
${ }^{36}$ A testament to both her resilience and amiability, Carol has fully and unapologetically embraced her nickname -- even using it in the titles of her memoirs Letters To My Grandchildren: Memoirs of a Dragon Lady - Volume I (Toronto: Resources Supporting Family \& Community Legacies Inc., 2014) and Letters To My Grandchildren: Memoirs of a Dragon Lady - Volume II (Toronto: Resources Supporting Family \& Community Legacies Inc., 2014).

${ }^{37}$ As the "Our History" page (http://caribbeanchinese.ca/Our-History) of the Chinese Caribbean Association website (accessed April 30, 2019) explains: "From a small group of people of Chinese background from the Caribbean, led by Hubert Lue and Louis Chong, it has grown into an active and vibrant organization with approximately 500 members today. Hubert and Louis first recognized the need of such an organization in late 1976 and quickly put together a steering committee to act as a catalyst in developing this Association. Following Hubert's leadership, Robert Chin, Fulford Chin Choy, Dr. Junior Wong, Osmond Lee, Kay Moosie, Eric Chong, Albert Lue, Dr. Ken Fung, Pamela Hew, Joselyn Cheong, Henry Williams, Hector Hoo Fatt, Nicey Chin, Carlton Wong, Cecil Chin Yee, Michael Akai, and Ken Chong formed the first steering committee" (emphasis added).

${ }^{38}$ Thomson, "Moving Stories," 34.
} 
interviews "explore and even challenge the myths and romanticisations which sometimes sustain individual and community identity but which conceal significant points of tension. ${ }^{39}$ For example, while some elder narrators speak proudly of the community for seeming to embody Jamaica's motto "Out of Many, One People," Jenna and Brian share stories about being openly gay Chinese Jamaicans that certainly trouble this narrative. While this MRP is not an "activist migrant or ethnic community oral history project" per se, other narrators "combat the silences and stereotypes which afflict [the] community" in very similar ways. ${ }^{40}$ Anne-Marie, for instance, ends her interview sharing her dream of a research center for the study of the Chinese in the Caribbean "in all their complexity." As she explains it, this institute would, among other things, investigate under-researched aspects of the community -- including how families managed relationships with children born outside of marriage.

Although I think this project is doing something important simply by recording memories and stories from those in the Chinese Jamaican community (particularly elders), it does feel like something truly special is happening in these moments of what Thomson calls "bearing witness" (which refers not only to the interviewer's "witnessing" of the narrator's recounted experience, but also the public's "witnessing" of it in recorded form). ${ }^{41}$ Of course, as John Ellis notes, "the only reality that documentary can truly bear witness to [is] that of an interaction between individuals at a particular time, each individual bringing to that situation their own expectations and understandings of what is going on, and how that will define how they ought to, and want to, behave." ${ }^{42}$ Again, though, this is something oral historians have long known, as the place of

\footnotetext{
39 lbid., 33.

40 Ibid., 30.

${ }^{41}$ Ibid., 31

42 John Ellis, Documentary: Witness and Self-Revelation (New York: Routledge, 2012), 45.
} 
intersubjectivity in theoretical work will attest. For Thomson, then, this kind of "bearing witness" is "empowering for individual narrators," and can help "generate public recognition of collective experiences which have been ignored or silenced." Closer to home, it might even contribute to healing "inter-generational rifts" as well. ${ }^{43}$ If the project is able to do this in the short term, then perhaps it will serve yet another purpose in the long run: namely, illustrating how "the meaning which migrants ascribe to their past experience, and the ways in which the life story is understood, remembered and told...change over time." ${ }^{.44}$

43 Thomson, "Moving Stories," 31.

${ }^{44}$ Ibid., 34. 


\section{Chapter Two: Methodology}

\section{i. Beginnings}

I first explored the possibility of focusing creative attention on the community while taking classes at the Center for Documentary Studies at Duke University in Durham, NC, during the summer of 2015. In one of my individual mentoring sessions with folklorist and oral historian Michelle Lanier, I mentioned my interest in creating some kind of documentary about my experience of the Chinese Jamaican community in Toronto. Michelle, who has West Indian family members herself, was very encouraging of the idea, and helpfully suggested audio as a medium. We discussed how this would, among other things, place special emphasis on Jamaican patois and dialectal features that might not be as common in another generation or so.

Shortly after I returned to Toronto from Durham, Ray Chen, a widely respected Chinese Jamaican photographer, began organizing local community members to think about a possibility that Michelle and I had also discussed: an oral history project. Ray began these meetings in August of 2015 with Jeanette Kong, Roger Chen, Robert Hew, Loraine Lee, and project narrators Carol and Patrick. After a preliminary discussion, Tsung Tsin Association of Ontario president Jennifer Chin, Anne-Marie, and Stephanie were invited to join the group as well. In addition, I decided to channel my documentary impulse into what seemed like a worthwhile, community effort by volunteering to serve as an interviewer and help advise the group on technical matters. ${ }^{45}$

In his initial email to the group, Ray stresses the importance of doing something to “document our history and our culture.” He continues: "Make no mistake: we are now the 'older generation' and the very last generation to hold this knowledge. Therefore it is up to our

\footnotetext{
${ }^{45}$ Ray Chen, email message to Carol Williams-Wong, Patrick A. Lee, Loraine Lee, Jeanette Kong, Roger Chen, Robert Hew, Anne-Marie Lee-Loy, Jennifer Chin, and Stephanie Lyn, August 26, 2015.
} 
generation to document our elders' experiences and ours before it is too late. ${ }^{\$ 46}$ Though not explicitly acknowledged in the email, the sense of urgency probably had something to do with the 2014 passing of one such elder: the aforementioned G. Raymond Chang.

Ray ends his email with an expansive vision for the project. "Our sons and daughters will have their own story, some of which we should include to show the continuity of our forefathers' generation," he writes. "We should also include the arrival of the new Chinese [immigrants] to the island [of Jamaica] and how they see themselves as a part of this document." ${ }^{47}$ What final form he envisions for the project is not totally clear in this first message, but Ray does allude to video content and also specifically mentions the possibility of a companion book.

By mid-September, though, a robust three-page project description (assembled by Stephanie) was circulated via email. Acknowledging the scope of the undertaking, it lays out a realistic timeline with five phases of work, as well as necessary roles and responsibilities. It also identifies possible collaborators and sponsoring organizations, including community associations, academic institutions, and government agencies. Finally, it suggests that interviews and other materials collected by the project would ultimately "be held and administered by [the Ryerson Centre for Immigration and Settlement]. ${ }^{948}$

Beyond obvious logistical concerns, Stephanie and I both wondered if opportunities in the online space weren't being overlooked. For my part, I had been following the development of the New York Public Library's Community Oral History Project, and was excited by it as a digital-first, rigorously community-based undertaking. ${ }^{49}$ Why were we not looking to something

\footnotetext{
${ }^{46} \mathrm{Ibid}$.

47 Ibid.

48 "Draft 2 (2015-09-17): Chinese-Jamaican Oral History Project," in the author's possession.

${ }^{49}$ See https://oralhistory.nypl.org.
} 
like that for inspiration, I wondered? In sharing her thoughts, however, Stephanie was much more eloquent and direct. In an October email to Jeanette and Anne-Marie, she expresses concerns that the group might be "missing the potential for breadth, depth, scope, and reach offered within the digital landscape." ${ }^{50}$ She continues: "Perhaps it's incumbent upon us (the younger and more tech savvy individuals) to make them aware of the possibilities of technology for achieving and furthering the aims of collecting, preserving, and sharing our culture beyond physical, geographic, and temporal boundaries." ${ }^{51}$

As it turns out, we were not the only ones with competing notions about what the project could be: more and more, it seemed that everything, even the original vision for the project, was up for grabs. Some were starting to advocate for a more traditional documentary film or series, while others pushed for producing books or other written resources, and still others had different ideas. The protracted deliberations that followed were to be expected from such a group process, of course, but the lack of resolution about the shape and scope of the project also began to interfere with practical progress. Among other things, the group had planned to apply for an Ontario Trillium Foundation grant in order to subsidize a full-time project manager, but were unable to settle on a final project description in time for the November deadline.

After failing to apply for the grant, the project seemed to stall. Then, very sadly, Ray passed away in February of 2016. He was, of course, the driving force behind the project, and so it seemed to die with him: in the months after his passing, the group exchanged no messages

\footnotetext{
${ }^{50}$ Anne-Marie, who in 2011 organized the Counter Cultures Network (http://countercultures.net/design), a conference and accompanying website for scholars interested in "how the shop counter has (and continues) to act as a cultural contact zone throughout the Chinese diaspora," was certainly sympathetic. And just days earlier, on September 25, 2015, Jeanette, a longstanding advocate for digital storytelling, had mused about the possibility of "a digital exhibit" similar to Brandon Stanton's popular photoblog Humans of New York (https://www.humansofnewyork.com/).

${ }^{51}$ Stephanie Lyn, email message to Jeanette Kong and Anne-Marie Lee-Loy, October 6, 2015.
} 
about the project. Nonetheless, Stephanie and I remained hopeful that we all would return to it eventually, if only to honor Ray's memory.

By the fall of 2016, I was applying to the MFA program at Ryerson. Since I considered the oral history project dormant but not aborted, I proposed a correlative but distinct MRP in my application. ${ }^{52}$ But by the time I matriculated to Ryerson in the fall of the following year, it was becoming apparent that there were no plans at all for the oral history project's future. So I decided to make it a reality with my MRP. This decision had a lot to do with my faith in Ray's vision, of course, but also my own passion for oral history as a documentary medium. For a long time I had been wanting to turn my own practice towards oral history, and bringing the Chinese Jamaican Oral History Project to life with the guidance and support of the MFA program seemed to be a constructive way of making that leap.

\section{ii. Stops and Starts}

As I began to pull things together in the first year of the program, a few distinctive elements of my approach to the project began to come into focus. First, I knew that it would exist as online archive. I felt that Stephanie was absolutely right about the internet's possibilities in terms of furthering the goals of the project. ${ }^{53}$ At the same time, I could also see roads not taken in

\footnotetext{
52 The proposed project was a domestic ethnography of sorts: a first-person essay film about my experience in the Chinese Jamaican community. I described something that would fit what Timothy Corrigan calls in his book The Essay Film: From Montaigne, After Marker (New York: Oxford University Press, 2011) as a "portrait essay film" -- a genre of nonfiction cinema that combines "intimate images" of documentary subjects with a framework that acknowledges the "centrality of subjectivity" in the filmmaker's pursuit (80). I specifically named Ross McElwee's Bright Leaves (2003), Sarah Polley's Stories We Tell (2012), and Geeta and Ravi Patel's Meet the Patels (2014) as touchstones in the application essay.

${ }^{53}$ Without knowing it, Stephanie was pointing to a reality that oral historians have been coming to grips with in a lot of recent theoretical and methodological writing -- namely, that providing meaningful access to archives in the digital age means taking advantage of the internet's many possibilities for expanding the scope of engagement. For example, in "Oral History and the Digital Revolution: Toward a
} 
comparable web-based projects. I was surprised, for example, that free, open-source, digital storytelling tools from places like the Knight Lab at Northwestern University were not being employed in any of the websites popping up in my research. ${ }^{54}$ I certainly had ideas about how some of these tools could be useful, especially as creative methods for providing background and context for the oral histories. In addition, there seemed to be room to raise the bar in terms of visual quality: though not always the case, the images in these projects sometimes came across as prosaic or perfunctory.

The second thing I decided was that I would audio-record the interviews, and take a still portrait of each narrator. To paraphrase Ira Glass, host of NPR's This American Life, I believe that oral history, like radio, is in and of itself "a very visual medium," but that if you can offer something to "picture as the story is told, something three-dimensional," then your audio can really "come alive." $" 55$ There were practical reasons for taking this approach as well. For one

\footnotetext{
Post-Documentary Sensibility," an important piece included in the second edition of editors Robert Perks and Alistair Thomson's The Oral History Reader (New York: Routledge, 2006), Michael Frisch states frankly: "The nicely cataloged but rarely consulted shelves of audio and video cassettes in even the best media and oral history libraries are closer than most people realize to that shoebox of unviewed home-video camcorder cassettes in so many families -- precious documentation that is inaccessible and generally unlistened to and unwatched" (102). Elsewhere, in "I Just Want to Click on It to Listen': Oral History Archives, Orality, and Usability," in his and Mary A. Larson's Oral History and Digital Humanities: Voice, Access, and Engagement (New York: Palgrave Macmillan, 2014), Douglas A. Boyd notes: "Free [digital] technologies and platforms....are now at our fingertips. We [oral historians] must quicken our transition, our mindsets and paradigms, and our archival workflows and procedures to adapt and accommodate users' expectations. When we do, our interviews will be used" (94). And tying everything together in "Sharing Oral History, " in her, Charles F. Ganzert, David H. Mould, Stephen H. Paschen, and Howard L. Sacks's Catching Stories: A Practical Guide to Oral History (Athens, OH: Swallow Press / Ohio University Press, 2009), Donna M. DeBlasio writes: "The Internet has become an increasingly important forum for disseminating oral history in a variety of formats that include lists of projects and interviews available at a variety of institutions, transcripts, and audio clips. The Web offers ways to incorporate oral histories into virtual exhibits and provides research tools for scholars and others who do not have to travel to the actual library or archive. For the hosting organization, Web development can be a more cost-effective way to make its interviews available literally to the whole world. With other new technologies such as podcasts, oral histories can reach whole new audiences who might not necessarily read a transcript, visit a museum, or go to a website to view a virtual exhibition" (207-8).

${ }^{54}$ See https://knightlab.northwestern.edu.

${ }_{55}^{5}$ Jessica Abel, Out on the Wire: The Storytelling Secrets of the New Masters of Radio (New York: Broadway Books, 2015), 25-6.
} 
thing, I wanted to bring qualities of attention and intimacy to the interviews; I knew that too

much technical apparatus (and any crew) would be a distraction for both myself and the

narrators. For another, an inkling told me that not everyone I wanted to include would be

comfortable doing an on-camera interview, but that few (if any) were likely to feel that way

about being audio-recorded or photographed. ${ }^{56}$

Finally, I knew that there would eventually need to be some sort of public presentation of the project. I imagined something close to the oral history exhibitions that I read about in my preliminary research: a listening environment that would include sound bites of audio, the portraits, text, and possibly even physical objects. Going into the second semester, though, I struggled to articulate much beyond this.

On top of this challenge, I was contending with self-consciousness about my role in bringing the project to life; I worried terribly that being a White settler and outsider made me completely the wrong person to launch the project. ${ }^{57}$ One of my initial ideas for dealing with this was to limit myself to interviewing family -- specifically, Stephanie, her parents, her brother, and

\footnotetext{
${ }^{56}$ As it turned out, when first approached, a few cautious narrators did indeed ask if they "had to" be interviewed on-camera.

${ }^{57}$ In fact, I became quite stymied by the midterm of our second semester, and decided to change my MRP topic. The project I temporarily focused on was an idea for "live documentary" performance about rotary jails and how these unusual facilities fit in the larger histories of mass surveillance and social control in the United States. The decommissioned Montgomery County Jail in my hometown of Crawfordsville, IN, is the only still-functional rotary jail in the country, and this offered a chance to put a personal spin on difficult material. This idea was not without its problems, however. In July of 2018 , I took an exploratory visit to Crawfordsville, and photographed the jail extensively. It quickly became clear, though, that at least one more (not inexpensive) visit to Crawfordsville would be necessary. I was also slow to recognize that the enormity and complexity of the subject made it ill-suited for the kind of short-form performance that would be appropriate for an MRP. In addition, I could not seem to let go of the Chinese Jamaican Oral History Project, and over the summer began to think of ways I could at least address some of the problems I had identified. And so, shortly before returning to Ryerson in the fall to begin my second year of the program, I changed my topic back. Funnily enough, however, the Joseph Armand Bombardier Canada Graduate Scholarship (Master's Program) from the Social Sciences and Humanities Research Council of Canada (SSHRC) that supported this MRP was granted based on an outline of proposed research for this idea.
} 
members of her extended family. For the purposes of the exhibition, I thought I could perhaps focus on their memories of Stephanie's maternal grandmother Marie, the matriarch of the family. When I presented this idea in the "Master's Project Development" course, though, Dr. Gerda Cammaer wondered if restricting things this way might make the project too insular. She recommended I interview at least a couple of people outside the family circle as well, especially if my intention was to help create something bigger than just a "family history project." Her comments struck me as right on the mark, and so I finally settled into the project.

\section{iii. Research}

At the start of fall 2018 semester, my first order of business was identifying an initial batch of narrators for the project. Most comparable projects have begun with a collection of interviews somewhere between six and twelve. The Brooklyn College Listening Project's recent effort We Are Brooklyn: Immigrant Voices, for example, made its debut as a website and multimedia exhibition with a total of ten narrators. ${ }^{58}$ Twelve seemed to me the right number for a robust start to the project, and so I set about identifying and contacting candidates.

Right away, I knew that I would include Stephanie, Joan, and Eustace. While all family stories are unique, their experiences could be considered representative of many Chinese Jamaican immigrants to Toronto. In addition, I knew that I would invite some of the members of Ray's original working group. Because Patrick and Anne-Marie had produced so many important resources for and about the community (a lot of them referenced herein), I made sure

${ }^{58}$ See https://wearebrooklyn.org. 
to contact them early on. Similarly, Carol's status as a prominent community leader -- as well as her experiences living in Jamaica, Hong Kong, and Canada -- made her another obvious choice.

Scanning the community more broadly, Keith loomed large because of his lifelong work around the Chinese Jamaicans' Hakka heritage. Tony also stood out, albeit in a different way: as a fixture of the Toronto media scene, he made for an excitingly distinguished narrator. Not wanting to overcrowd the project with too many public figures or usual representatives, however, I looked for more candidates like Stephanie and her parents as well -- those we might think of by comparison as “everyday people.” Ultimately, I invited two such individuals I have gotten to know well and am fond of: Stephanie's aunt Kay, and her childhood friend Suzanne.

I should say too that the selection process was also greatly influenced by Chinese Trinidadian artist Richard Fung's work. As Tao Leigh Goffe notes, Fung's video art "mine[s] oral histories and family archives" in a way that "rupture[s] the surface of family images to trouble the bourgeois, heteronormative, and colorist scripts that often police the formation of family." 59 It reminded me to make sure to include narrators whose family lives didn't necessarily fit those aforementioned scripts -- particularly LGBTQIA+ voices. ${ }^{60}$ Through Stephanie, I was aware of Jenna work, though neither of us had ever met her. Nonetheless, I reached out and she was willing to participate. When I later spoke to Jenna about my efforts to find more

\footnotetext{
59 Tao Leigh Goffe, "Albums of Inclusion: The Photographic Poetics of Caribbean Chinese Visual Kinship," Small Axe: A Caribbean Journal of Criticism 22, no. 2 (2018): 35.

${ }^{60}$ Seeing Richard Fung's work was an important reminder of something Linda Shopes suggests in her article "Oral History and the Study of Communities: Problems, Paradoxes, and Possibilities" for the Journal of American History 89, no. 2 (2002): "...[D]efine the universe of narrators broadly. ... Ask: Whom am I missing? ... Including a range of narrators simultaneously deepens the inquiry and extends it outward, helping us understand both the internal complexity of the community under study and its relationship to a broader historical process" (596-7).
} 
LGBTQIA+ narrators, in part so that she would not be a "token" voice, she connected me with Brian.

\section{iv. Oral Histories and Portraits}

All of the oral history interviews and portraits were conducted between September 2018 and June 2019. A few portraits were taken at the time of their respective interviews, but most occurred on separate dates. Most of the interviews were recorded in narrators' homes and workplaces, although one, Keith's, was recorded in an editing suite at the School of Image Arts on Ryerson's campus. Only one, Stephanie's, was re-recorded: she was the first interview, but the conversation guide (see below) grew and developed so much over the course of the project that we both decided to do her interview again so she could speak to questions not originally asked. Three narrators -- Eustace, Tony, and Brian -- required photo reshoot sessions. In Tony's case, this was due to equipment malfunctioning during our first session. In Eustace and Brian's cases, it was simply due to my dissatisfaction with the results of their first sessions.

For each interview, I used a general conversation guide ${ }^{61}$ adapted from the "Family History Sample Outline and Questions" published online by the UCLA Center for Oral History Research ${ }^{62}$ as well as material in the appendices of Paul Thompson and Joanna Bornat's The Voice of the Past: Oral History. ${ }^{63}$ The questions I assembled and formulated were also influenced by my reading about the community, cross-cultural oral history, and best practices for interviewing immigrant narrators. In addition, I solicited advice from narrators themselves about

\footnotetext{
${ }^{61}$ See Appendix B.1.

62 "Family History Sample Outline and Questions," UCLA Center for Oral History Research, accessed March 1, 2019, http://www.oralhistory.library.ucla.edu/familyHistory.html.

${ }^{63}$ Paul Thompson and Joanna Bornat, The Voice of the Past: Oral History, Fourth Edition (New York: Oxford University Press, 2017), 393-402.
} 
my list of questions, and the guide grew and changed over time. ${ }^{64} \mathrm{I}$ also asked narrators

follow-up questions when appropriate, as well as questions specific to any unique experiences. ${ }^{65}$

I also drew up a Creative Commons license form for project narrators. ${ }^{66}$ Adapted from a similar document found in Barbara W. Sommer and Mary Kay Quinlan's The Oral History

Manual, ${ }^{67}$ it is an agreement to share the interview and portrait under the terms of a Creative Commons Attribution-NonCommercial-NoDerivatives 4.0 International License (CC

BY-NC-ND 4.0) ${ }^{68}$ Such forms are standard for oral history projects, but, in this case, it was one of the key ways I addressed ethical concerns as well. As Carol McKirdy argues, "with immigrant community oral history projects, ownership of the project should come from the immigrant community. ${ }^{\circ 9}$ Because this is (at present) more of a cross-cultural oral history project, one way I can ensure that ownership at least never quite leaves the community is through my agreements with the narrators. Therefore, I have inverted the language to make it clear that, in every case, both the recorded interview and the portrait are the property of the narrator -- they retain the copyrights. I as the interviewer have permission to use these materials online and in the

\footnotetext{
${ }^{64}$ For example, Stephanie suggested that I specifically ask narrators, "What does being Chinese Jamaican mean to you?" This provoked an interesting range of answers indeed. Similarly, Jenna encouraged me to explicitly ask narrators about colonialism, not just implicitly or when it came up organically -- a suggestion very much in keeping with the spirit of Richard Fung's films. As Tao Leigh Goffe notes in his article "Albums of Inclusion: The Photographic Poetics of Caribbean Chinese Visual Kinship" for Small Axe: A Caribbean Journal of Criticism 22, no. 2 (2018), Fung's work actively "interrogates the afterlife of the nineteenth-century European colonial experiment of Chinese indenture" (35; emphasis added).

${ }^{65}$ For instance, I asked Anne-Marie and Keith questions about their respective academic careers and scholarship on the Chinese Jamaican community. I also asked Brian and Jenna about their experiences coming out.

${ }^{66}$ See Appendix B.2.

${ }^{67}$ Barbara W. Sommer and Mary Kay Quinlan, The Oral History Manual, Third Edition (Lanham, MD: Rowman \& Littlefield, 2018), 120.

68 "Attribution-NonCommercial-NoDerivatives 4.0 International (CC BY-NC-ND 4.0)," Creative Commons, accessed March 1, 2019, https://creativecommons.org/licenses/by-nc-nd/4.0.

${ }^{69}$ Carol McKirdy, Practicing Oral History with Immigrant Narrators (New York: Routledge, 2015), 22.
} 
exhibition, but any other use (by me or anyone else) is at the discretion of the individual narrator.

Each narrator signed two copies of the form: one that they kept, and one that was returned to me.

For the portraits, I simply set out to complement each narrator's audio with a high-quality image that captured something of their personality visually -- much like Tamara A. Fleming's portrait series "Newark Leaders" for the Queer Newark Oral History Project, ${ }^{70}$ or Katja Heinemann's work on The Graying of AIDS: Stories from an Aging Pandemic ${ }^{71}$. However, these are both examples of studio portraiture, which was not a direction I ever wanted to go. Instead, I photographed each narrator in a space that was both convenient and comfortable for them.

\section{v. Website}

For the website, I decided to hew closely to how most other online oral history projects are designed. The vast majority -- including all of the projects mentioned above -- use a grid layout on their homepage to showcase their entire portfolio of interviews. Typically, each oral history interview also has its own unique page that includes (1) the complete audio recording, (2) a high-resolution portrait and any other available images, and (3) interview metadata. ${ }^{72}$ In this

\footnotetext{
${ }^{70}$ See https://queer.newark.rutgers.edu.

${ }^{71}$ See https://agrayingpandemic.org.

${ }^{72}$ Many also include a transcript (in HTML and/or PDF form) for each interview, and a thorough system of audio tags. I hope to add these features in the future, but it was not realistic to expect that I would finish them in time for the project's launch as part of DocNow 2019. It seemed to me that there were two ways to address these lacks. First, I could show the holes on the site. The New York Public Library's Community Oral History Project, for example, makes a point of showing users what's missing ("transcript not yet available," etc.). Considering the size of its interview collection, these missing pieces probably seem understandable to most users; for the more modestly-sized Chinese Jamaican Oral History Project to launch with similar notations, however, might seem chintzy by comparison. So the second option: designing the site without obvious places for these features. There are projects that exclude transcripts and/or audio tagging -- including the Louie B. Nunn Center for Oral History at the University of Kentucky's Haiti Memory Project (https://www.haitimemoryproject.org), Lynn Lewis's Picture the Homeless Oral History Project (https://picturethehomelessoralhistoryproject.com), and We Are Brooklyn: Immigrant Voices -- and I have taken pages from their streamlined presentations of audiovisual material. Once the transcripts and tagging system are finished, they will be seamlessly integrated. Until then, the site will look clean, not inelegant, and seemingly "complete."
} 
case, "interview metadata" means something more reflexive than a dry collection of information: each interview includes my first-person comments about the narrator, including the reasons I chose to interview them, any necessary disclosures about my relationship to them, and reflections about the interview itself. This is one of the ways I strove to both be transparent and up-front in acknowledging my positionality.

In order to achieve all of this, I made the decision to use Wordpress.com. ${ }^{73}$ I chose Wordpress.com over Wordpress.org for two main reasons. First, I felt that Wordpress.org offered far more options (and complications) than I actually needed in terms of building the site; the flexible, premium theme for Wordpress.com that I eventually purchased gave me all the creative controls I felt were needed and then some, not to mention an agreeable baseline look. Second, because I hope to see full ownership of the project return to the Chinese Jamaican community in the future, I wanted administration of the site to be easily transferable -- as simple as passing along a short list of passwords whenever the time comes. This is certainly much easier to do with Wordpress.com than Wordpress.org.

In addition, I purchased the URL “cjohp.org,” as most oral history websites generally employ a URL with "ohp" somewhere in their address. I also added multiple other pages at the site, including (1) an "About" page that details the project and its mission" ${ }^{74}$; (2) a blog for news updates $^{75}$; (3) a bibliography page that outlines further resources by and about the Chinese Jamaican community ${ }^{76}$; (4) a page with a contact form (that relays messages to the project email account at cjohpeditor@gmail.com $)^{77}$ and links to Facebook ${ }^{78}$, Twitter $^{79}$, Instagram $^{80}$, YouTube ${ }^{81}$,

${ }^{73}$ See https://www.cjohp.org.

${ }^{74}$ See https://cjohp.org/about.

${ }^{75}$ See https://cjohp.org/blog.

${ }^{76}$ See https://cjohp.org/resources.

${ }^{77}$ See https://cjohp.org/contact. 
LinkedIn $^{82}$, and Tumblr ${ }^{83}$ accounts; and (5) a pages for the interactive timeline ${ }^{84}$ feature created with the Knight Lab's Timeline JS tool.

As indicated above, I was drawn to the Knight Labs tools for their possibilities in terms of providing background and context -- which is precisely what the Timeline JS feature does here. It tells a linear narrative that begins with the arrival of the first Chinese indentured labourers to Jamaica and continues into the present. Because a Google account is required to use Timeline JS, I am also using it for both the aforementioned email as well as backup cloud storage, saving copies of all audiovisual and textual materials in Google Drive. In addition, the oral history interview recordings are archived with and effectively hosted by the Internet Archive.$^{85}$ I chose the Internet Archive over other audio hosting services because of its status as a member of the American Library Association and its mission "to provide Universal Access to All Knowledge. ${ }^{\nexists 66}$ Using their platform felt very much in keeping with my tendency to use free and open-source software whenever possible. ${ }^{87}$ Also, as with Wordpress.com, their service makes both transferability that much easier.

Though I had originally planned to include a dropbox feature at the website, allowing for anyone and everyone in the community to contribute oral history interviews and portraits, I

\footnotetext{
${ }^{78}$ See https://facebook.com/cjohpdotorg.

${ }^{79}$ See https://twitter.com/CJOHPdotorg.

${ }^{80}$ See https://instagram.com/cjohpdotorg.

${ }^{81}$ See https://www.youtube.com/channel/UCue9sKb_X1vgjvHrKit0uzw.

${ }^{82}$ See https://www.linkedin.com/company/cjohpdotorg.

${ }^{83}$ See https://cjohpdotorg.tumblr.com.

${ }^{84}$ See https://cjohp.org/timeline.

${ }^{85}$ See https://archive.org/details/@the_chinese_jamaican_oral_history_project.

86 "About the Internet Archive," Internet Archive, accessed March 15, 2019, https://archive.org/about/.

${ }^{87}$ I share this inclination with oral historian Douglas A. Boyd, who writes in "I Just Want to Click on It to Listen': Oral History Archives, Orality, and Usability," in his and Mary A. Larson's Oral History and Digital Humanities: Voice, Access, and Engagement (New York: Palgrave Macmillan, 2014): "We need to encourage open access and usage of the recorded interviews where and when appropriate and make oral histories accessible using platforms such as the Digital Public Library of America (DPLA)" (95).
} 
received some useful feedback on this from none other than Richard Fung. During his visit to our "Master Class" with Sara Angelucci, he called the audiovisual material I gathered "impeccable," and worried that an open door for submissions might contribute to problematic dynamics within the community. Following up in a message he sent through Sara, Richard further explained that "two registers of audio/image production values on the website...would reinforce what is often a problematic hierarchy in communities where some people are regarded, and regard themselves, as leaders/spokespeople, and others as less important. This is often tied to class." He noted that if the project is meant "to represent the community in its entirety, it's important to [continue] to be as democratic and egalitarian as possible" vis-à-vis picture and sound quality ${ }^{88}$ Instead of a dropbox, then, Richard suggested that I instead identify others in the community who might be willing to help record and photograph narrators at or near the standard set by the first twelve. He added that such team-building might also be an important step in terms of my intention to eventually return ownership of the project to the community. ${ }^{89}$

\section{vi. Exhibition}

When I presented the MRP-in-progress in our "Master Class," my concept for the exhibition was (at that point) quite large indeed. Among other things, I planned to have objects in a display case, mounted tablets for user-directed exploration of the website, and participatory elements. The central element in the space, though, would have been a single-channel video

\footnotetext{
${ }^{88}$ Sara Angelucci, email message to Daniel Clarkson Fisher, March 28, 2019.

${ }^{89}$ While I took all of Richard's advice, I also felt that there needed to be some method for sharing submissions (solicited and unsolicited) from the community. Because many Tumblr themes are built for submissions, I chose one and have dedicated that space (https://cjohpdotorg.tumblr.com) -- separate and apart from CJOHP.org -- for showcasing anything interested parties would like to share with the project's audience there.
} 
presentation playing the twelve digital stories (one for each narrator) on a loop. As McKirdy notes, "digital storytelling is an ideal method to seamlessly blend, coordinate, and store the significant and illustrative associated material often gathered when doing an oral history"; hence its primary role in the exhibition. ${ }^{90}$

Sara and Richard both agreed that I was doing a lot -- probably too much. Knowing that I have invitations to speak about the Chinese Jamaican Oral History Project at community organizations and conferences in the future, they had the same suggestion: simply "forefront" the digital stories with the Ryerson exhibition, and leave the participatory elements for those future engagements within the community. As Sara succinctly put it, "show off what you've gathered [in the exhibition] -- the participatory work can happen elsewhere."

After talking things through with my advisor, Dr. Blake Fitzpatrick, I decided that, instead of the "pop-up museum" (Richard's phrase), I would instead present the digital stories as a single-channel projection in the Image Factory at the School of Image Arts. ${ }^{91}$ This would give me a much more straightforward way of achieving the result I was really after: sharing some of the strongest pieces of audio, and amplifying their effects with accompanying visuals. It was that simple, so I chose simplicity.

McKirdy outlines three possible approaches to digital storytelling. The first approach requires generating unique narrator audio (distinct from the oral history interview), and the third approach uses multiple pieces of audio from across an interview or series of interviews to create a single digital story. ${ }^{92}$ I was most drawn to the second approach, though, which she refers to as "the digital story [as] representative of the full interview." In this approach, one "selected sound

\footnotetext{
${ }^{90}$ McKirdy, 103.

${ }^{91}$ See Appendix A.1 - A.4.

${ }_{92}$ McKirdy, 104-6.
} 
bite," or "short clip of speech extracted from the complete audio" of an interview, is used to "[make] the full audio more accessible to a wider audience because of its comparative brevity." If the right sound bite is selected, and the resultant digital story serves it well, then, "ideally, listeners will be motivated to listen to the complete [interview] recording," McKirdy writes. ${ }^{93}$

Obviously, the first step in making these digital stories was selecting a sound bite to represent each oral history interview. This meant something no longer than three or four minutes in each case, for a combined runtime of hopefully no longer than thirty-five or forty minutes (to be played on a loop). As I selected these moments, I was mindful of the work of Elizabeth Cowie, who has written:

What distinguishes the video and film installation from other gallery media such as painting and sculpture, but also from film and video projected in a cinema, is the way it demands -- and performs -- a new positioning of audio-spectatorship, of encountering the sounds and images. In the gallery the audio-spectator is mobile, perhaps just passing through, physically engaged by and traversing a space that has been designed for her movement in and around it, perhaps staying two minutes or ten minutes. ${ }^{94}$

Accordingly, I went looking for the most compelling examples of storytelling in each interview; I wanted every digital story to be a rewarding listen in and of itself, especially since some "audio-spectators" might only experience one (or even just part of one). At the same time, I was also wanting to make sure that all these vignettes flowed together naturally and complemented one another; while I don't expect very many people will watch all the stories in one sitting, I did want to make sure that there would be an edifying and satisfying chronological sequence for

\footnotetext{
93 Ibid., 105.

${ }^{94}$ Elizabeth Cowie, "On Documentary Sounds and Images in the Gallery," Screen 50, no. 1 (2009): 125, doi:10.1093/screen/hjn076.
} 
anyone who did. As I began to assemble a radio edit, then, I decided to organize the pieces in such a way that they told a story from start to finish. ${ }^{95}$

Next, the selected audio was paired with images. Originally, I had thought about letting the portraits alone stand with the audio and the transcript, in much the same way that the public oral history project StoryCorps ${ }^{96}$ shares digital stories on their YouTube channe $1^{97}$. However, Blake encouraged me to use archival and other images as well -- which certainly improved more than a few of the digital stories. Though I had always planned to transcribe the audio as well, if only for reasons of accessibility, this played better on a computer screen than as a projection. As a result, I excluded the transcript from the digital stories themselves. I also produced a small takeaway postcard with the URL and one of the portraits (Kay's). ${ }^{98}$ These were placed on a plinth near the intro panel to the exhibition.

\footnotetext{
${ }^{95}$ For instance, the pieces that come first in the edit find narrators reflecting on ancestors in China (e.g. Keith and Carol), while those towards the middle focus mainly on life in Jamaica leading up to immigration to Canada (e.g. Kay and Eustace), and those near the end have more to do with contemporary life in Canada (e.g. Brian and Jenna).

${ }^{96}$ See https://storycorps.org.

${ }_{97}^{97}$ See https://www.youtube.com/user/storycorps.

${ }^{98}$ See Appendix A.5.
} 


\section{Chapter Three: Documentary Relevance}

\section{i. Oral History as Documentary Mode and Medium}

Talking about how this MRP fits within the documentary tradition necessarily involves taking a position that shouldn't be controversial, but apparently is: that oral history is both a documentary mode and medium unto itself. ${ }^{99}$ Within the field of oral history, this is not only widely accepted, but deeply explored; much of the academic work referenced herein attests to this, not to mention the existence of institutes like the Center for Oral History and Digital Storytelling at Concordia University, where I was invited to present about the Chinese Jamaican Oral History Project as part of their sixth annual Emerging Scholars Symposium on Oral History, Digital Storytelling, and Creative Practice in March of 2019. However, even though schools like the Center for Documentary Studies at Duke include it fully among other documentary arts, oral history tends to get comparatively short shrift elsewhere in documentary studies. ${ }^{100}$ The third and

\footnotetext{
${ }^{99}$ When I speak of oral history as a documentary medium, I suppose I mean a committed practice that manifests itself in one of two ways. It might be as a dedicated work within a preexisting medium -literature, audio, new media, performance, film, etc. (I am thinking, for example, of the books of Studs Terkel and Svetlana Alexievich, or the one-woman plays of Anna Deavere Smith.) Or it might be a practice that exemplifies what has been called "platform-agnosticism" -- a movement between mediums based on either other overriding commitments or the needs of particular projects. (Here, I am thinking of Dave Isay's public history project StoryCorps, which produces radio segments, video, books, animated short films, digital storytelling, mobile apps, and much more.) Katerina Cizek is credited with coining this term, and notes in an interview with Sarah Wolozin for the MIT Open Documentary Lab's "New Digital Storytelling Series" that she has "worked in all forms of media: photography, print, video, radio, and, of course, digital" (https://docubase.mit.edu/lab/interviews/the-new-digital-storytelling-series-katerina-cizek; accessed May 10, 2019).

100 In addition, oral historians have generated a good deal of theoretical work about the merger of filmmaking and oral history. For example, as Sarah-Jane Walton writes in her article "Historian as Filmmaker: Reflections on the Making of the Film Documentary Those Dying Days" for South African Historical Journal 68, no. 4 (2016): "Film...lends itself in many insistent ways to the practice and presentation of oral history. ... [Oral historian] Alessandro Portelli was one of the first to look beyond memory as a potentially unstable resource for factual information and to view it instead as the creation of meaning. His call for the recognition of oral sources as equal in worth and use as written sources, or any other source-forms, bears resemblance to arguments for film as a historic medium. Indeed, for Portelli, it is often the emotional truths found in memories and the ways in which these memories might have changed over time, rather than the accuracy of the memories themselves, that is most revealing. Both film and oral history, then, do well in dealing with interior thoughts and representations of emotion" (637).
} 
most recent edition of Bill Nichols's go-to textbook Introduction to Documentary, for example, is only the first to include (very fleeting) discussion of oral history as a method of nonfiction filmmaking. ${ }^{101}$ "Oral history has been very much at the methodological center of a wave of highly successful documentary films," Michael Frisch observes. "So much so, perhaps, that its particular characteristics as a mode for presenting history to audiences have been easy to take for granted." 102 Still, this lack of regard is remarkable when one considers both the sheer number and inarguable quality of these films, including no less than Claude Lanzmann's Shoah (1985). ${ }^{103}$

Some of this devaluing of oral history may have to do with the fallacy of presumption that it is something only academic historians do. ${ }^{104}$ In fact, as the Oral History Association explains, practitioners not only represent "various disciplines," but come from "both inside and outside the academy." ${ }^{105}$ And, of course, neither of the best-known practitioners of oral history -iconic American broadcaster Studs Terkel and Belarusian investigative journalist Svetlana Alexievich -- were trained as historians. Part of a tradition often called "literary oral history," their work is usually placed within creative nonfiction. It artfully employs oral historical

\footnotetext{
${ }^{101}$ Bill Nichols, Introduction to Documentary, Third Edition (Bloomington, IN: Indiana University Press, 2017), 106; 149.

102 Michael Frisch, A Shared Authority: Essays on the Craft and Meaning of Oral and Public History (Albany, NY: State University of New York Press, 1990), 147.

${ }^{103}$ Other essential titles here include the Mariposa Film Group's Word Is Out: Stories of Some of Our Lives (1977); Stewart Bird and Deborah Shaffer's The Wobblies (1979); Trinh T. Minh-ha's Surname Viet, Given Name Nam (1989); Thom Andersen and Noël Burch's Red Hollywood (1996); Spike Lee's diptych When the Levees Broke: A Requiem in Four Acts (2006) and If God Is Willing and da Creek Don't Rise (2010); Jia Zhangke's 24 City (2008); David France's How to Survive a Plague (2013); Pol Cruchten's hybrid adaptation of Svetlana Alexievich's Voices from Chernobyl (2016); Keith Maitland's Tower (2016); Wang Bing's Dead Souls (2018); and Peter Jackson's They Shall Not Grow Old (2018).

${ }^{104}$ As if to illustrate this fallacy, Donna M. DeBlasio, Charles F. Ganzert, David H. Mould, Stephen H. Paschen, and Howard L. Sackst, the editors of Catching Stories: A Practical Guide to Oral History (Athens, OH: Swallow Press / Ohio University Press, 2009), all come from different backgrounds, including history, journalism, media production, and performance.

105 Oral History Association, "OHA Principles and Best Practices," last modified October 2018, https://www.oralhistory.org/principles-and-best-practices-revised-2018/.
} 
methods, albeit in ways that are sometimes distinct from (but not necessarily antithetical to) the ways academic and community historians use them. ${ }^{106}$

Curiously enough, however, another reason for the scant attention to oral history might be its perceived artlessness in some corners of documentary studies and criticism. For example, Renov (questionably) declares many films made in the oral history mode insufficiently "interrogative," dismissing them as mere "[aggregates] of private histories strung together or nimbly intercut"107 Similarly, in a mixed review of Lanzmann's Shoah: Four Sisters (2018), critic Lawrence Garcia betrays a belief that documentary film and oral history are mutually exclusive. "There's a lingering impression that [Lanzmann] has fashioned more of a document -a pure oral history -- than anything else," he concludes. ${ }^{108}$

By contrast, another critic, Matt Zoller Seitz, sees in the film ...minimalist directing of a high order, practically invisible in its choices and effects, but...unquestionably indicative of a very particular style -- one that aims to create the conditions necessary to birth a compelling though understated remembrance of unimaginable pain. The story is shaped in the process of recording it, rather than being excessively manipulated after the fact. ${ }^{109}$

As it happens, these observations are actually quite resonant with a lot of oral history theory.

Gerald Zahavi could be speaking for a number of practitioners when he writes:

Visual oral history and online documentary work...will challenge our emphasis on orality, as [they introduce further layers] of content to be recorded and analyzed by scholars. All of these layers will make the field that much more exciting in the future, but...the central concern of oral historians will remain the same: building a trusting space

\footnotetext{
${ }^{106}$ Doreen G. Fernandez, "An Experience in Literary Oral History," Philippine Studies 35, no. 4 (1987): 488-98.

${ }^{107}$ Michael Renov, "Towards a Poetics of Documentary," in Theorizing Documentary, ed. Michael Renov (New York: Routledge, 1993), 27.

${ }^{108}$ Lawrence Garcia, "Shoah: Four Sisters Extends the Legacy of Claude Lanzmann's Essential Holocaust Film," The AV Club, last modified November 13, 2018, https://film.avclub.com/shoah-four-sisters-extends-the-legacy-of-claude-lanzma-1830374735. 109 Matt Zoller Seitz, "Shoah: Four Sisters," RogerEbert.com, last modified November 14, 2018, https://www.rogerebert.com/reviews/shoah-four-sisters-2018.
} 
for dialogue, generating probing and effective questions, developing deep listening skills, and producing sophisticated interpretations of orally expressed memories. ${ }^{110}$

This is not to say that oral history practitioners do not work visually, but rather that they are most interested in the kinds of images that are not typically brought to the fore in other kinds of documentary work -- specifically, the visual memories of narrators, and the listeners' visual imaginations. Hearkening back to Ira Glass's notion of radio as inherently “a very visual medium," the best oral histories not only manage to convey something of a narrator's mental pictures, but also generate further images in the minds of those who hear them. This seems to be precisely what Paul Buhle is driving at in his introduction to comic book writer Harvey Pekar's Studs Terkel's Working: A Graphic Adaptation when he says: "The work of Studs Terkel has been 'visual' from the beginning, and a comic art book based upon a selection of his interviews in the totemic oral history volume Working would seem the natural extension of his essential impulses." ${ }^{111}$ Within oral history theory, we also find Sean Field's intriguing writings on "imagining memories." ${ }^{\prime 12}$ As Amy Starecheski explains:

Field [emphasizes] the visual aspects of the memory process by defining images in the mind's eye as the foundational materials from which memories are imagined. The oral historian, Field argues, must empathically imagine interviewees' stories in her or his mind's eye, and attention to this process can yield deeper insights into the intersubjective experiences at the heart of the oral history dialogue. This is an interpretive framework with exciting potential, especially as it draws our attention to the dynamic processes linking experience, memory, and storytelling, and it provides a way to begin thinking about the elements of experience not remembered and of memory not narrated. ${ }^{113}$

\footnotetext{
${ }^{110}$ Gerald Zahavi, "Notes from the Field: Digital History and Oral History," in Oral History and Digital Humanities: Voice, Access, and Engagement, eds. Douglas A. Boyd and Mary A. Larson (New York: Palgrave Macmillan, 2014), 131.

111 Paul Buhle, introduction to Studs Terkel's Working: A Graphic Adaptation, adapted by Harvey Pekar, ed. Paul Buhle (New York: The New Press, 2009), xxiii.

112 Sean Field, Oral History, Community and Displacement: Imagining Memories in Post-Apartheid South Africa (New York: Palgrave Macmillan, 2012), 1.

${ }^{113}$ Amy Starecheski, "Oral History, Community and Displacement: Imagining Memories in Post-Apartheid South Africa," Oral History Review 40, no. 2 (2013): 468, https://doi.org/10.1093/ohr/oht074.
} 
Because so many of its narrators excel at creating opportunities for "imagining

memories," the Chinese Jamaican Oral History Project points up and revels in precisely this kind of aural-visual storytelling. For instance, in the digital story created from Carol's interview, which uses her aforementioned memories about watching the films of Nancy Kwan, the quality of her storytelling in this regard is especially high -- so much so that when I workshopped an early version of the digital story in Vid Ingelevics's "Master's Project Production II" course, the overwhelming feedback I received was to use fewer images, as the class felt they sometimes actually detracted from Carol's audio. Similarly, I was loathe to use very many images in Brian’s digital story because the sound bite (about his sexual orientation and how his mother does and does not show her acceptance of it) was so powerfully affecting all by itself.

Of course, as Alexander Freund and Alistair Thomson well note, "oral history and photography intersect at important epistemic points: evidence, memory, and storytelling." 114 Sometimes, in decidedly reflexive projects, these intersections are used to throw more light on intersubjectivity. ${ }^{115}$ But in many other cases, like this one, they serve to unambiguously illustrate, supplement, and augment the interviews. Stephanie's portrait is a particularly good example of this one-to-one approach. In her interview, she spends a lot of time remembering her beloved

\footnotetext{
${ }^{114}$ Alexander Freund and Alistair Thomson, "Introduction: Oral History and Photography," in Oral History and Photography, eds. Alexander Freund and Alistair Thomson (New York: Palgrave Macmillan, 2011), 2. 115 In their piece "From Witness to Participant: Making Subversive Documentary," in Alexander Freund and Alistair Thomson's Oral History and Photography (New York: Palgrave Macmillan, 2011), Al Bersch and Leslie Grant describe examples of "alternative documentary forms and social practices" that ought to cause any readers who still strive for them to "reconsider authenticity and objective recording as goals for ethnographic research" (190). They continue: “...[W]e take the position...that documentary forms such as photography and oral history are constructions of, rather than, windows to reality, and that the meanings produced through these forms are subject to change and interpretation. Stuart Hall writes, 'meaning does not inhere in things, in the world. It is constructed, produced.' He explains, 'if meaning is the result, not of something fixed out there, in nature, but of our social, cultural and linguistic conventions, then meaning can never be finally fixed.' This acknowledgment of the constructed nature of meaning opens up the possibility for documentary, ethnographic, and artistic practices that move beyond historical evidence and instead encourage ongoing, democratic interpretations of everyday life" (188).
} 
maternal grandmother, Marie. At one point in this part of her oral history, she reflects on a snapshot that I took of the two of them and what it means to her, especially now that Marie has passed away. For the portrait, then, I photographed Stephanie holding a framed copy of the picture, underlining its importance in the interview.

The decision to eschew a more self-referential approach comes partially out of my efforts to cultivate a positive White racial identity: again, I do not feel that it is appropriate for me to use images, memories, and stories from the Chinese Jamaican community for the purposes of my own conceptual navel-gazing. But it is also very much in keeping with oral history theory. As Mary A. Larson puts it:

What is important -- in fact, what is absolutely critical -- is that we examine our deepest beliefs about the nature of oral history and then act on them when we select media and interfaces. We need to be very introspective about the mediating effects of our choices, how they impact access, context, and curation, and how those impacts, in turn, bear upon the ways in which people can make meaning from oral history. ${ }^{116}$

This sort of straightforward, non-reflexive approach could also be said to fit very well within Nichols's "discourse of sobriety" -- or, a documentary stance in which "style is secondary to content; content is what counts -- the real world as it exists or existed." ${ }^{117}$ At any rate, again, I situate this MRP within the imminently recognizable (but not always properly recognized) tradition of documentary art that employs oral history as mode or medium unto itself. Its multifarious legacy includes the work I have discussed in this section, and more. ${ }^{118}$ Tying my

\footnotetext{
${ }^{116}$ Mary A. Larson, “'The Medium Is the Message': Oral History, Media, and Mediation,' Oral History Review 43, no. 2 (2016): 337, doi: 10.1093/ohr/ohw052.

117 Nichols, 192.

${ }^{118}$ Among many other examples, this work would include the "American Life Histories" of the Federal Writers' Project; graphic nonfiction like Joe Sacco's Footnotes in Gaza (2009); performance pieces like Anna Deveare Smith's Twilight: Los Angeles, 1992 (1994); verbatim theater like Moisés Kaufman and the members of the Tectonic Theater Project's The Laramie Project (2000); audio documentaries and podcasts like APM Reports and the National Museum of American History's Order 9066; and all the cutting-edge new media, digital storytelling, and research-creation projects referenced throughout this paper.
} 
MRP and all these disparate efforts together is the shared belief that, in the words of Annette

Day:

Whatever choices are made, it is...vital to achieve an appropriate balance between the technology and the content of the exhibition, to avoid compromising the aims of the exhibition. It is too easy to be distracted from the content by new and exciting technology, allowing the latter to drive the presentation and distracting attention from the oral history itself that should be the raison d'être for including the technology. Ultimately, the physical way in which oral history is displayed must not be allowed to marginalise, overwhelm or distract attention unnecessarily from what is actually being said, because it is here that the real value lies. ${ }^{119}$

\section{ii. "Thick Vision" in Digital Storytelling}

Exactly what this "balance between the technology and the content of the exhibition" looks like can be somewhat elusive. Day, for instance, offers "one possible solution" in the example of an exhibit that gave visitors "something at which to look without being too distracting." ${ }^{\prime 20}$ Similarly, while Carol McKirdy’s aforementioned typology of digital stories brings a much-appreciated degree of precision to thinking about them, it still does not tell us very much about what separates a high quality digital story from a pro forma audiovisual montage.

On the one hand, as Martin Lucas notes, any artistic approach to oral history automatically "differentiates" itself because "clearly, science, even social science, can’t live inside affect, or subjectivity [the way art does]." ${ }^{121}$ On the other hand, though, when it comes to visual treatment, practitioners should probably aim higher than just "something at which to look without being too distracting." To this end, Kathleen M. Ryan's notion of "thick vision" is

\footnotetext{
${ }^{119}$ Annette Day, “Listening Galleries: Putting Oral History on Display," Oral History 27, no. 1 (1999): 95.

120 Ibid., 94.

${ }^{121}$ Martin Lucas, "Documentary: Trauma and an Ethics of Knowing," Post Script 36, nos. 2-3(2017): 101, http://link.galegroup.com.ezproxy.lib.ryerson.ca/apps/doc/A532995704/AONE?u=rpu_main\&sid=AONE\&x id=a27c721a.
} 
especially useful. With apologies to the eminent oral historian Alessandro Portelli, "thick vision" is born out of "thick dialogue" -- the "detail-laden conversation and analysis by narrators found in the best oral history interviews." ${ }^{22}$ (There is some overlap here with McKirdy's use of the term "sound bites.") She continues:

Thick dialogue is transformed in the public sphere through documentary and multimedia storytelling into thick vision, as it were -- a way to bring the understanding of the oral history conversation into the larger public sphere via both the words of the oral history narrator and varied visual artifacts to deepen the audience's understanding of the story. This is a knowledge that can only be obtained through this merger. ${ }^{123}$

As I looked for examples of "thick vision" in my research, two projects stood out. The first was Dave Isay's public oral history project StoryCorps. ${ }^{124}$ If anyone has "cracked the code" here, it is certainly StoryCorps. The digital stories housed under their "Story of the Week" playlist on YouTube ${ }^{125}$ are especially striking in their standardized simplicity: as the interview audio plays, a split screen shows (typically) a single photograph of the narrator and interviewer together on one side, and the transcript on the other. Although the audio (which is usually not much longer than two-and-a-half minutes) is often fairly affecting all by itself, the addition of these other elements consistently elevates things into the realm of "thick vision." There tends to be an interesting contrast offered by the portrait (a particularly somber sound bite might be paired with a comparatively warm and bright photograph, for example), and the transcript is always perfectly synced to the audio, very effectively emphasizing pauses in speech through understated motion graphics.

\footnotetext{
${ }^{122}$ Kathleen M. Ryan, "Beyond Thick Dialogue: Oral History and the 'Thickening' of Multimedia Storytelling," Visual Communication Quarterly 22, no. 2 (2015): 86, doi:10.1080/15551393.2015.1042160. ${ }^{123}$ Ibid., 93. 
Because the digital stories in my MRP include multiple images, however, I was also eager to find examples of "thick vision" that incorporated more than a single portrait.

Thankfully, Blake turned me onto Michel Huneault's Post Mégantic. As described by the Center for Documentary Studies at Duke, this project "incorporates photographs, videos, oral histories, and installations to tell the story of Lac-Mégantic, Quebec, where on the night of July 6, 2013, a cargo train from North Dakota carrying nearly 8 million liters of shale oil derailed and exploded, killing 47 people and effectively destroying the town." ${ }^{26}$ Though not digital storytelling per se, this multifaceted, multimedia work includes pieces that are useful to consider. For example, the video installation component "Echoes," which Huneault calls "central to the exhibition," brings together still images, "the voices of the Méganticois," and transcripts of their interview audio. ${ }^{127}$ A montage of full-sized photographs, presented with the bilingual transcript superimposed across the center of the images while the audio plays, its effect is immediately arresting and mesmerizing throughout; it is "thick vision" of a very different sort than StoryCorps, but "thick vision" nonetheless.

For my exhibition, I split the difference stylistically, trying to borrow from both Huneault's contemplative approach to montage and StoryCorp's simple tricks for ensuring that a narrator's personality really shines through a digital story. Given the material I had to work with, the project's digital stories took one of two forms. In the first case, exemplified by Patrick's digital story, a single portrait and a series of archival images work together to complement the audio. In Patrick's sound bite, he talks about living directly across the street from the Chinese

${ }^{126}$ Center for Documentary Studies at Duke University, "2015 Lange-Taylor Prize: Michel Huneault 'Post Mégantic'," accessed May 1, 2019, https://documentarystudies.duke.edu/awards/lange-taylor/prizewinners/2015.

${ }_{127}$ Michel Huneault, "La longue nuit de Mégantic - vidéo Échos (Extrait | Excerpt)," Vimeo Video, 1:36, January 29, 2015, https://vimeo.com/120403191. 
Benevolent Association in Kingston, and his memories of the annual Chinese New Year celebrations there. The digital story, then, cuts between Patrick's portrait and various archival images showing exactly the celebrations to which he refers.

In the second case, exemplified by Anne-Marie's digital story, a series of images from the portrait session(s) work together to complement the audio. In a few cases, I had many usable photographs taken during my photo shoot(s) with a narrator. Edited together, they not only serve to remind us of what Stella Bruzzi refers to as the "performative" nature of documentary ("because they acknowledge the construction and artificiality of even...non-fiction [work]"), but offer a more multifaceted look at that narrator. ${ }^{128}$ In Anne-Marie's digital story, which uses the aforementioned sound bite about her wanting to create a research center for the study of the Chinese in the Caribbean, I have edited together images from my visit to one of her undergraduate classes. In them, we see a very dynamic range of her professorial "looks," ending with her final portrait (which shows her offering one of her students a very warmhearted smile).

I should say too that criticism of digital storytelling has also informed the development of the exhibition. Sarah Zenaida Gould, for example, raises excellent points about how digital stories might undercut audiences' "patience to listen." I certainly spent time asking myself if I felt is was an "[overmanipulation of] oral history [to] select clips and edit them into a slick two-minute video," and whether or not this gives a "false impression that oral histories are polished or perfect histories." ${ }^{129}$ Similarly, I wrestled with concerns about storytelling in general. In Alexander Freund's scathing appraisal of StoryCorps, for instance, he writes: "The storytelling phenomenon, which frequently aligns itself with (or appropriates) oral history,

\footnotetext{
${ }^{128}$ Stella Bruzzi, New Documentary: A Critical Introduction (New York: Routledge, 2000), 8.

${ }^{129}$ Sarah Zenaida Gould, "Challenges in Exhibiting Oral History," OUPblog (blog), March 4, 2016, https://blog.oup.com/2016/03/exhibiting-oral-history/.
} 
reinforces neoliberal values of competitive individualism and thus depoliticizes public discourse." ${ }^{130}$ This was constructive food for thought, even if, ultimately, I came to share Elizabeth Miller, Edward Little, and Steven High's conclusion: that Freund's “call for a return to a certain critical distance within oral history can be read as a disciplinary appeal to police boundaries," and also "ignores the underlying political discomfort with the academic gaze that contributes to the popularity of storytelling as a research-creation methodology." 131

That said, the digital storytelling approach still presents me with some "political discomfort." To paraphrase Ryan, "the transference of [an oral history interview] into a [something like a digital story] will always be fraught with...tension" -- specifically, "between the shared authority of the interview and the individual authorship of the [digital story]."132 Among other things, she observes that this process usually entails "[treating] narrators [like] sources," excluding some voices altogether. ${ }^{133}$ While this MRP includes a digital story for every participating narrator, they are definitely not co-created; I am the one making all of the sound bite selections and corresponding creative choices. There are practical reasons for individual authorship here, of course: considerations for the entire series of digital stories go well beyond each narrator's own digital story, so the only logical way to share authority would be to produce the entire series with the input of all twelve narrators together at every turn. However, this means that the Chinese Jamaican Oral History Project, which aspires to be a community oral history project, finds itself in exactly the kind of tension Ryan describes.

\footnotetext{
${ }^{130}$ Alexander Freund, "Under Storytelling's Spell? Oral History in a Neoliberal Age," Oral History Review 42, no.1 (2015): 96, https://doi.org/10.1093/ohr/ohv002.

${ }^{131}$ Elizabeth Miller, Edward Little, and Steven High, Going Public: The Art of Participatory Practice (Vancouver: UBC Press, 2017), 17.

${ }_{132}$ Ryan, 92; 93.

133 Ibid., 92.
} 


\section{Conclusion: From Cross-Cultural to Community Oral History Project}

As Miller, Little, and High explain:

In recent years, following the lead of Michael Frisch, oral historians have been urged to "share authority" with their interview partners and source communities. Frisch originated the term in 1990 to describe the shared authority of the oral history interview between the expert authority of the researcher and the experiential authority of the interviewee. Since then, this idea has evolved into a wider and more profound sharing of authority over the entire history-making process. Learning with rather than simply about represents a fundamental shift in knowledge production -- one that breaks the disciplinary illusion of the omniscient historical narrator or curator. ${ }^{134}$

The Chinese Jamaican Oral History Project began with Ray Chen's vision for such an undertaking; hence my wish to see it truly become that. As mentioned above, I see it in its current state as a cross-cultural oral history project, and one that is very much individually authored when it comes to choices around sharing and exhibition. While I feel that the MRP does successfully demonstrate how, in Thomson's words, an outsider-documentarian “and community members [can] participate on equal terms, contribute their different expertise and have a 'shared authority" in terms of the interviews, it is still very far from a community oral history project with shared authority in the sense that Miller, Little, and High speak about it. ${ }^{135}$

Of course, Linda Shopes is correct that “"community oral history' is a protean term, invoked by scholars and grass-roots historians alike to describe a variety of practices developed for a variety of purposes." ${ }^{\prime 136}$ At the same time, it seems to me that if literal shared authority has no real bearing on how the term is used, then it is not especially meaningful. For me, using the term requires, at a minimum, putting into practice the beliefs expressed by the various "oral

\footnotetext{
${ }^{134}$ Elizabeth Miller, Edward Little, and Steven High, Going Public: The Art of Participatory Practice (Vancouver: UBC Press, 2017), 11.

135 Thomson, "Moving Stories," 33.

${ }^{136}$ Linda Shopes, "Oral History and the Study of Communities: Problems, Paradoxes, and Possibilities," The Journal of American History 89, no. 2 (2002): 588, doi:10.2307/3092177.
} 
historians, media producers, and theater artists" interviewed for Miller, Little, and High's Going Public: The Art of Participatory Practice: that "art, story-sharing, and public engagement are essential to strengthening democratic processes; a shared commitment to collaboration and shared authorship strengthens the work we do; opening up otherwise closed research and artistic processes fundamentally changes the relationship to source or host communities, thus mitigating some of the recurring political and ethical problems of voyeurism and appropriation; collaboration and public engagement place ethics at the heart of our research and creative practice; and working across differences over time generates insight that can effect social and political change."137

The Chinese Jamaican Oral History Project does presently put some of these beliefs into practice. Others, though, remain goals for the future. What it will look like as a community oral history project is not for me alone to say: by definition, a great many things will have to be decided collaboratively within the community of Chinese Jamaican persons (and other participants). Though these beliefs necessarily challenge deeply embedded ideas about ownership and authorship within both the social science and documentary media-making, I am convinced that they are what is required to fulfill the promise of oral history as both a mode of historical inquiry and a documentary art. And fulfilling that promise is certainly no less than this project's narrators, and the wider Chinese Jamaican community, deserve.

Word Count: 10,901

${ }^{137}$ Miller, Little, and High, back matter; 263. 


\section{Appendix A.1}

\section{The Chinese Jamaican Oral History Project}

HD video projections with sound, varying lengths (looped)

June 19-30, 2019 | cjohp.org

Narrators: BRIAN CHANG, SUZANNE KONG, PATRICK A. LEE, DR. ANNE-MARIE LEE-LOY, DR. KEITH D. LOWE, EUSTACE LYN, JOAN LYN, STEPHANIE LYN, KAY MOOSIE, JENNA TENN-YUK, CAROL WILLIAMS-WONG, and TONY WONG

\section{Interviewer / Curator: DANIEL CLARKSON FISHER}

The Chinese Jamaican Oral History Project is an initiative that aims to record and preserve memories and stories from the Chinese Jamaican community in Toronto. Its online archive hosts (among other things) audio-recorded oral history interviews, narrator portraits, and relevant documents.

This exhibition, which draws on the contents of that archive, is comprised of twelve digital stories -- one for each of the narrators who has participated in the project so far. In every case, a soundbite has been selected to represent a complete interview. Together with new and old images, these voices tell a story of the Chinese Jamaican community in Toronto, while also underscoring the diverse range of individual experiences within it.

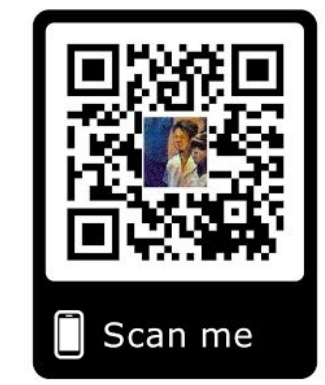


Appendix A.2

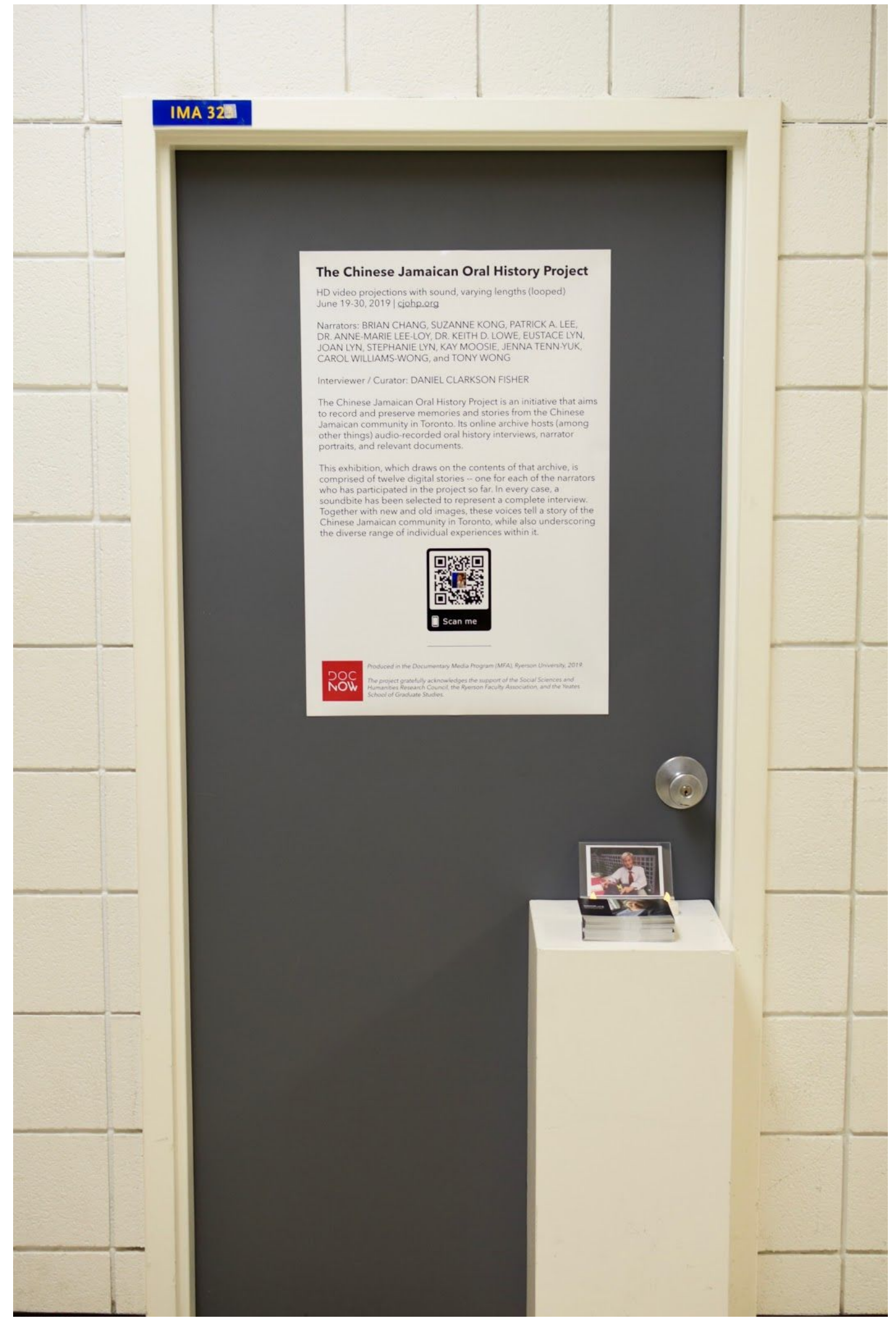


Appendix A.3
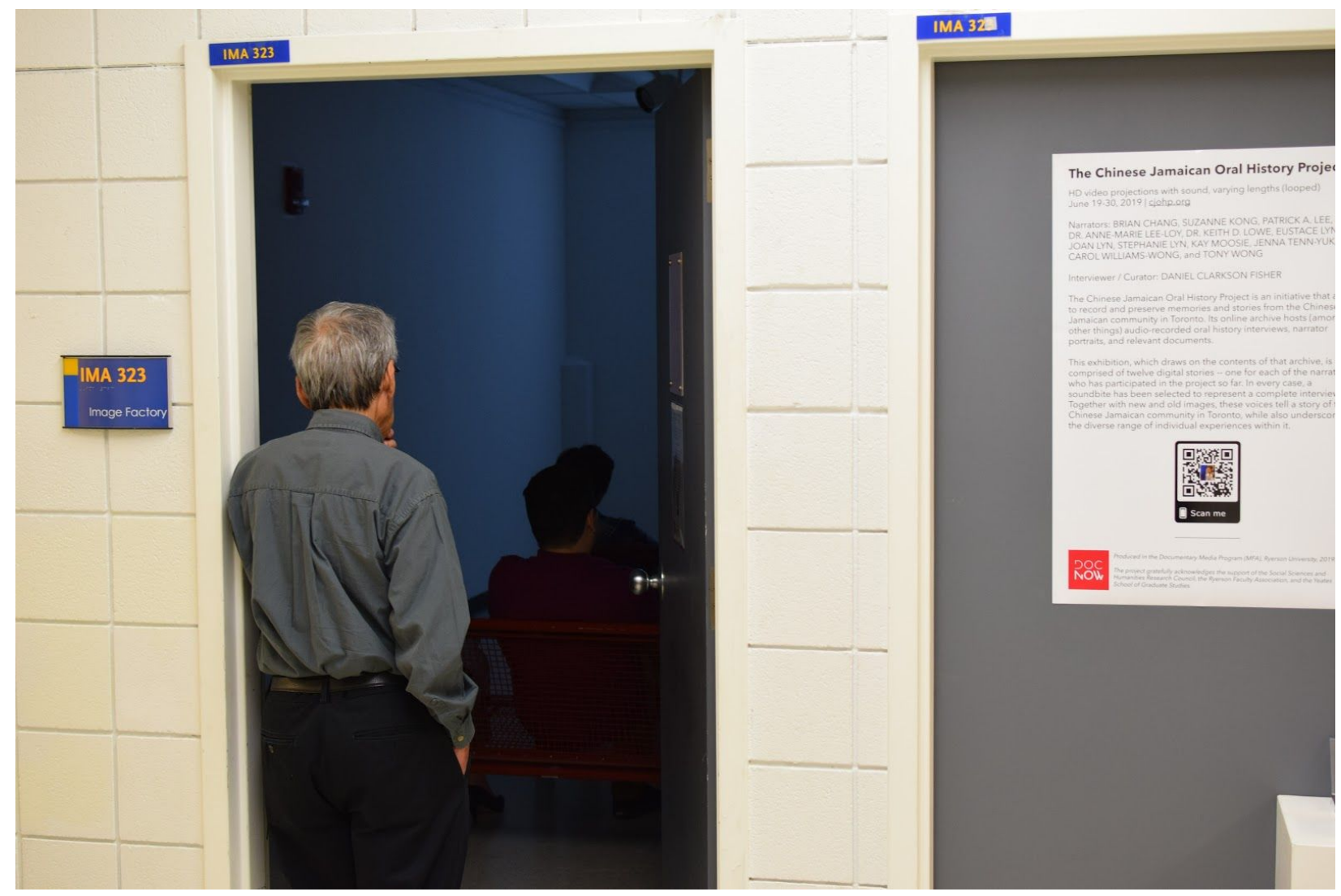


\section{Appendix A.4}

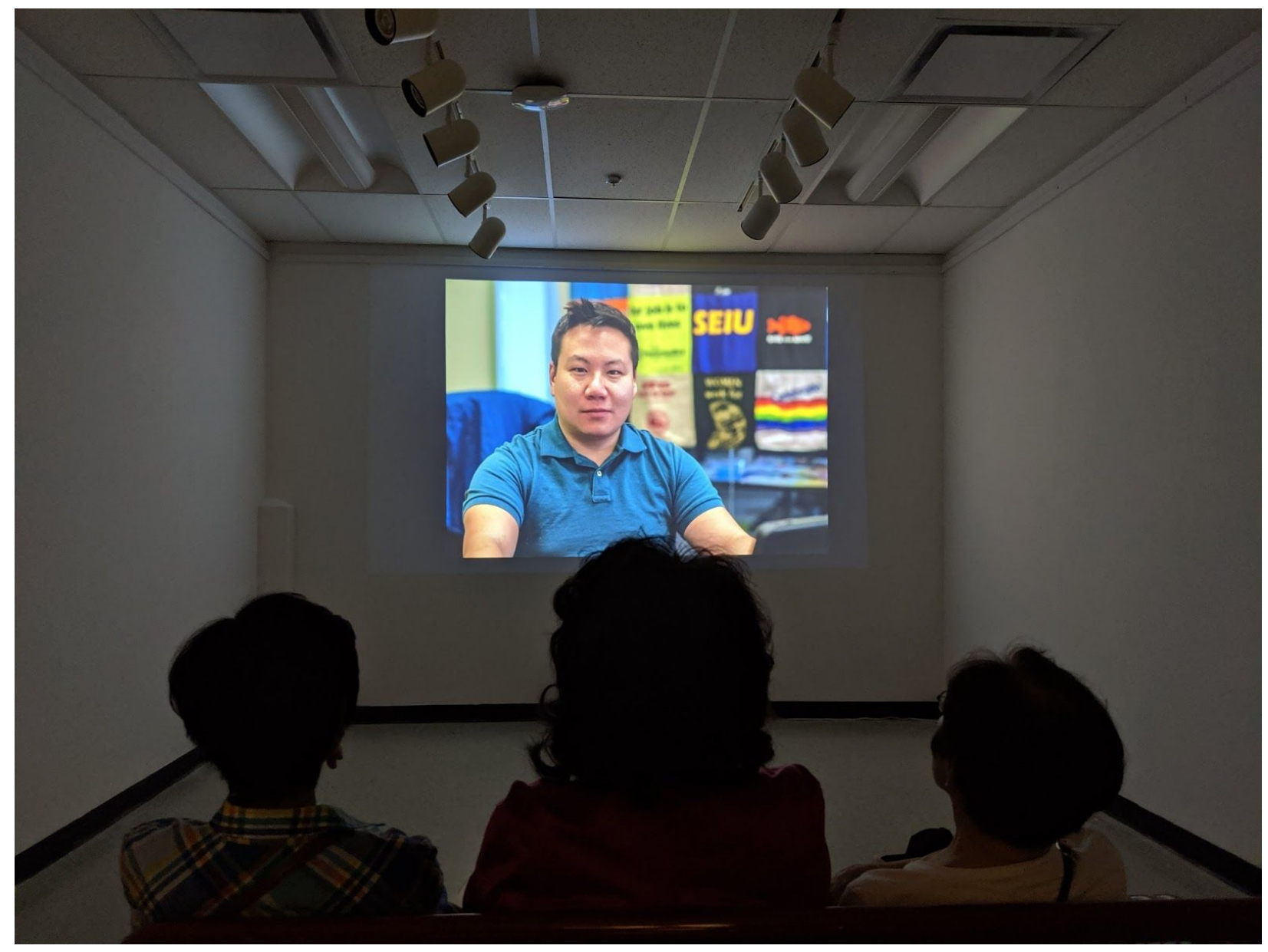

(Photo by Brian Chang) 


\section{Appendix A.5}

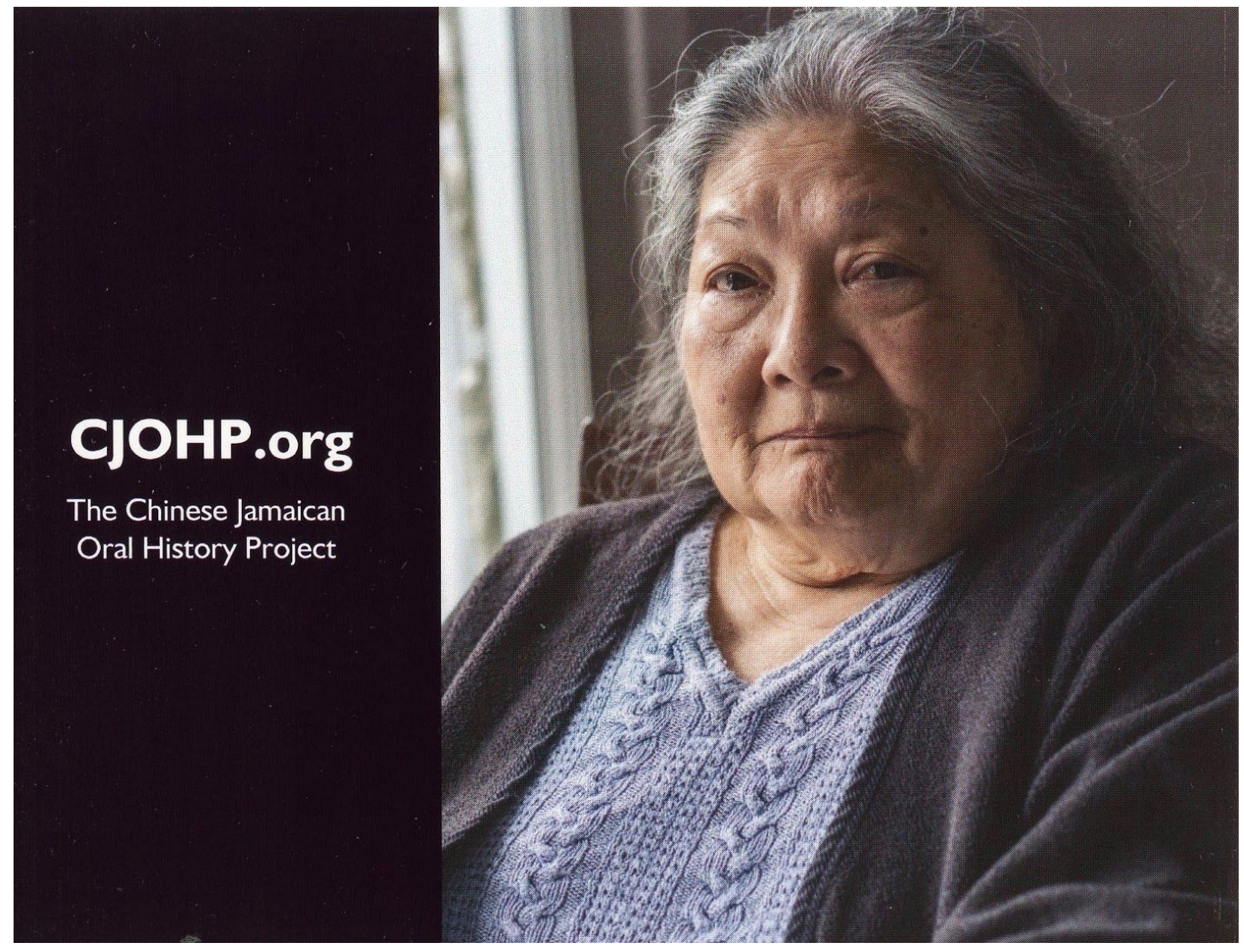




\section{Appendix B.1:}

\section{The Chinese Jamaican Oral History Project: Conversation Guide}

Adapted from the UCLA Center for Oral History Research's "Family History Sample Outline and Questions"

and Appendices in Paul Thompson and Joanna Bornat's The Voice of the Past: Oral History (Oxford University Press, 2017)

- When and where were you born?

- Tell us about your parents or your family background.

- Where were your Chinese ancestors from?

- What did your parents do for a living? Did you contribute to the family income or help parents in their work in any way?

- What was your parents' religious background?

- What, if any, organizations or associations were they involved in?

- What other relatives did you have contact with growing up?

- What do you remember about your grandparents?

- What stories did you hear about earlier ancestors whom you never knew?

- How many children were in the family, and where were you in the line-up?

- Describe what your siblings were like. Who were you closest to?

- Describe the home you grew up in.

- What were your family's economic circumstances?

- Describe your neighborhood.

- Describe the community you grew up in.

- Tell us about your understanding of the Chinese Jamaican community generally.

- What were you told, both positive and negative, about Chinese Jamaicans inside your family? Outside of it? Did you experience discrimination?

- What was school like for you? What were your favorite subjects? Particular interests?

- Who were your friends and what did you do when you got together?

- When and how did you/your family come to immigrate to Canada? What were some of your/their experiences and difficulties beginning a life in a new country?

- Describe your working life -- from your first job to now. In terms of your work, what are you most proud of?

- Tell us about your family now -- your spouse, children, grandchildren. What family traditions did you try to establish?

- Describe your involvement with the Chinese Jamaican community today.

- What does being Chinese Jamaican mean to you?

- Is there anything I haven't asked you about that you'd like to share?

- Knowing that this interview will be included in the Chinese Jamaican Oral History Project archive, what would you like to say to future generations of Chinese Jamaicans? 


\section{Appendix B.2:}

\section{The Chinese Jamaican Oral History Project: Creative Commons License}

Adapted from Barbara W. Sommer and Mary Kay Quinlan's The Oral History Manual: Third Edition (Rowman and Littlefield, 2018)

The mission of the Chinese Jamaican Oral History Project is to document and preserve the voices of Chinese Jamaican people around the world. The major part of this effort is the collection of oral history interviews and photographs.

Thank you for participating in our project. Please read and sign this gift agreement to release your interview and photograph for future use. Before doing this, read it carefully and ask questions you may have about its terms and conditions.

\section{AGREEMENT}

I, , voluntarily agree to be interviewed and photographed for this oral history project.

I understand that my interview and photograph may be distributed to the public for educational purposes, including formats such as print, public programming, and the internet.

Alos, I agree to freely share my interview and photograph under the terms of a Creative Commons Attribution-NonCommercial-NoDerivatives 4.0 International License (CC BY-NC-ND 4.0). This means that I retain the copyright, but that the public may freely copy and redistribute these items for noncommercial purposes, if they include the original source information and don't change them in any way. In return, the interviewer promises to send digital copies of the interview recording, transcript, photograph, and related items to the email listed here:

\section{NARRATOR}

Name (print)

Signature

Date

\section{INTERVIEWER}

Name (print)

Signature

Date 


\section{Bibliography / Mediography}

Abel, Jessica. Out on the Wire: The Storytelling Secrets of the New Masters of Radio. New York: Broadway Books, 2015.

Abrams, Lynn. Oral History Theory. New York: Routledge, 2010.

Alexievich, Svetlana. "A Search for Eternal Man: In Lieu of Biography." Accessed March 15, 2019. http://alexievich.info/en/.

---. Voices from Chernobyl: The Oral History of a Nuclear Disaster. Translated by Keith Gessen. New York: Picador, 2006.

“American Life Histories: Manuscripts from the Federal Writers' Project, 1936 to 1940.” Library of Congress. Accessed May 5, 2019.

https://www.loc.gov/collections/federal-writers-project/about-this-collection.

Andersen, Thom, and Noël Burch, dir.. Red Hollywood. 1996; New York: Cinema Guild, 2014. DVD.

APM Reports and the National Museum of American History. Order 9066. Accessed May 5, 2019. https://www.apmreports.org/order-9066.

"Attribution-NonCommercial-NoDerivatives 4.0 International (CC BY-NC-ND 4.0)." Creative Commons. Accessed March 1, 2019. https://creativecommons.org/licenses/by-nc-nd/4.0.

Basch, Linda, Nina Glick Schiller, and Cristina Szanton Blanc. Nations Unbound: Transnational Projects, Postcolonial Predicaments and Deterritorialized Nation-States. New York: Routledge, 1993.

Bersch, Al, and Leslie Grant. "From Witness to Participant: Making Subversive Documentary." In Oral History and Photography, edited by Alexander Freund and Alistair Thomson, 187-201. New York: Palgrave Macmillan, 2011.

Bing, Wang, dir. Dead Souls. 2018; New York: Icarus Films, 2019. DVD.

Bird, Stewart, and Deborah Shaffer, dir. The Wobblies. 1979; New York: Docurama, 2006. DVD.

Boyd, Douglas A. “Archiving the Promise of Oral History in a Digital Age." In The Oxford 
Handbook of Oral History, edited by Donald A. Ritchie, 285-302. New York: Oxford University Press, 2012.

---. “I Just Want to Click on It to Listen': Oral History Archives, Orality, and Usability.” In Oral History and Digital Humanities: Voice, Access, and Engagement, edited by Douglas A. Boyd and Mary A. Larson, 77-96. New York: Palgrave Macmillan, 2014.

Brooklyn College Listening Project, The. We Are Brooklyn: Immigrant Voices. Accessed March 1, 2019. https://wearebrooklyn.org.

Broussard, Albert S. "Race and Oral History." In The Oxford Handbook of Oral History, edited by Donald A. Ritchie, 186-201. New York: Oxford University Press, 2011.

Bruzzi, Stella. New Documentary: A Critical Introduction. New York: Routledge, 2000.

Buhle, Paul. Introduction to Studs Terkel's Working: A Graphic Adaptation, xxiii-xxv. Adapted by Harvey Pekar. Edited by Paul Buhle. New York: The New Press, 2009.

Butler, Toby. "The Historical Hearing Aid: Located Oral History from the Listener's Perspective." In The Oral History Reader (3rd ed.), edited by Robert Perks and Alistair Thomson, 536-55. New York: Routledge, 2015.

Center for Documentary Studies at Duke University, The. "2015 Lange-Taylor Prize: Michel Huneault 'Post Mégantic'.” Accessed May 1, 2019. https://documentarystudies.duke.edu/awards/lange-taylor/prizewinners/2015.

Chen, Ray. The Shopkeepers: Commemorating 150 Years of the Chinese in Jamaica 1854-2004: A Historical Record of Their Arrival and Personal Stories of Their Endeavours and Experiences. Markham, ON: Periwinkle Publishers Inc., 2005.

Cheng, Nien Yuan. “'Flesh and Blood Archives': Embodying the Oral History Transcript," Oral History Review 45, no. 1 (2018): 127-142, doi:10.1093/ohr/ohx071.

Clark, Andrew F. "The Challenges of Cross-Cultural Oral History: Collecting and Presenting Pulaar Traditions on Slavery from Bundu, Senegambia (West Africa)." Oral History Review 20, no. 1/2 (1992): 1-21. Accessed December 4, 2018. http://www.jstor.org/stable/3674851.

Corrigan, Timothy. The Essay Film: From Montaigne, After Marker. New York: Oxford University Press, 2011. 
Counter Cultures Network. "What is the Counter Cultures Network?" Accessed March 15, 2019. http://countercultures.net/design/about-us/.

Cowie, Elizabeth. "On Documentary Sounds and Images in the Gallery," Screen 50, no. 1 (2009): 124-134, doi:10.1093/screen/hjn076.

Cruchten, Pol, dir. Voices from Chernobyl (La Supplication). 2016; Luxembourg: Red Lion, 2018. Online.

Day, Annette. "Listening Galleries: Putting Oral History on Display." Oral History 27, no. 1 (1999): 91-96. Accessed December 4, 2018. http://www.jstor.org/stable/40179598.

DeBlasio, Donna M. "Sharing Oral History." In Catching Stories: A Practical Guide to Oral History, edited by Donna M. DeBlasio, Charles F. Ganzert, David H. Mould, Stephen H. Paschen, and Howard L. Sacks, 196-212. Athens, OH: Swallow Press / Ohio University Press, 2009.

Ellis, John. Documentary: Witness and Self-Revelation. New York: Routledge, 2012.

"Family History Sample Outline and Questions." UCLA Center for Oral History Research. Accessed March 1, 2019. http://www.oralhistory.library.ucla.edu/familyHistory.html.

Fernandez, Doreen G. “An Experience in Literary Oral History.” Philippine Studies 35, no. 4 (1987): 488-98.

Field, Sean. Oral History, Community and Displacement: Imagining Memories in Post-Apartheid South Africa. New York: Palgrave Macmillan, 2012.

France, David, dir. How to Survive a Plague. 2013; Orland Park, IL: MPI Home Video, 2013. DVD.

Freund, Alexander. "Oral History as Process-Generated Data." In The Canadian Oral History Reader, edited by Kristina R. Llewellyn, Alexander Freund, and Nolan Reilly, 218-238. Montreal \& Kingston: McGill-Queen's University Press, 2015.

---. "Towards an Ethics of Silence? Negotiating Off-the-Record Events and Identity in Oral History." In Oral History Off the Record: Toward an Ethnography of Practice, edited by Anna Sheftel and Stacey Zembrzycki, 223-238. New York: Palgrave Macmillan, 2013. 
---. "Under Storytelling's Spell? Oral History in a Neoliberal Age." Oral History Review 42, no. 1 (2015): 96-132, https://doi.org/10.1093/ohr/ohv002.

Freund, Alexander, and Alistair Thomson. "Introduction: Oral History and Photography." In Oral History and Photography, edited by Alexander Freund and Alistair Thomson, 1-23. New York: Palgrave Macmillan, 2011.

Frisch, Michael. "Oral History and the Digital Revolution: Toward a Post-Documentary Sensibility." In The Oral History Reader, Second Edition, edited by Robert Perks and Alistair Thomson, 102-114. New York: Routledge, 2006.

---. A Shared Authority: Essays on the Craft and Meaning of Oral and Public History. Albany, NY: State University of New York Press, 1990.

Funderburk, Alissa. "The Work of An Artist in the Words of Friends: Using Oral History as Art." Columbia Center for Oral History Research (blog), December 19, 2017. http://www.ccohr.incite.columbia.edu/blog/2017/alissa-funderburk-moma-rauschenbergamong-friends-review.

Fung, Richard, dir. My Mother's Place. 1990. Video.

Garcia, Lawrence. "Shoah: Four Sisters Extends the Legacy of Claude Lanzmann's Essential Holocaust Film." The AV Club. Last modified November 13, 2018. https://film.avclub.com/shoah-four-sisters-extends-the-legacy-of-claude-lanzma-1830374 735 .

Goffe, Tao Leigh. "Albums of Inclusion: The Photographic Poetics of Caribbean Chinese Visual Kinship." Small Axe: A Caribbean Journal of Criticism 22, no. 2 (2018): 35-56.

Gould, Sarah Zenaida. "Challenges in Exhibiting Oral History.” OUPblog (blog), March 4, 2016. https://blog.oup.com/2016/03/exhibiting-oral-history/.

Green, Anna. “Can Memory Be Collective?” In The Oxford Handbook of Oral History, edited by Donald A. Ritchie, 96-111. New York: Oxford University Press, 2011.

Heinemann, Katja, and Naomi Schegloff. The Graying of AIDS: Stories From An Aging Pandemic. Accessed March 1, 2019. https://agrayingpandemic.org.

Hudson, Dale, and Patricia R. Zimmerman. Thinking Through Digital Media: Transnational 
Environments and Locative Places. New York, NY : Palgrave Macmillan, 2015.

Huneault, Michel. "La longue nuit de Mégantic - vidéo Échos (Extrait | Excerpt)." Vimeo video, 1:36. Posted January 29, 2015. https://vimeo.com/120403191.

Internet Archive. "About the Internet Archive.” Accessed March 15, 2019. https://archive.org/about/.

Jackson, Peter, dir. They Shall Not Grow Old. 2018; Burbank, CA: Warner Home Video, 2019. DVD.

Janovicek, Nancy. "Oral History and Ethical Practice after TCPS2." In The Canadian Oral History Reader, edited by Kristina R. Llewellyn, Alexander Freund, and Nolan Reilly, 73-97. Montreal \& Kingston: McGill-Queen's University Press, 2015.

Jarvis-Tonus, Jill. "Legal Issues Regarding Oral Histories.” In The Canadian Oral History Reader, edited by Kristina R. Llewellyn, Alexander Freund, and Nolan Reilly, 98-116. Montreal \& Kingston: McGill-Queen's University Press, 2015.

Katz, David. Solid Foundation: An Oral History of Reggae. Minneapolis, MN: Jawbone Press, 2012.

Kaufman, Moisés, and the members of the Tectonic Theater Project. The Laramie Project. New York: Vintage Books, 2001.

Kong, Jeanette, dir. The Chiney Shop. 2012; Toronto: Ms. Chin Productions, 2012. DVD.

---, dir. Finding Samuel Lowe: From Harlem to China. 2014; New York: Virgil Films and Entertainments, 2016. DVD.

---, dir. Half: The Story of a Chinese Jamaican Son. 2013; Toronto: Ms. Chin Productions, 2013. DVD.

Labelle, M., Serge Larose, V. Piché, and Channon Oyeniran. "Caribbean Canadians." Last modified May 3, 2019.

http://www.thecanadianencyclopedia.ca/en/article/caribbean-people/.

Lanzmann, Claude, dir. Shoah. 1985; New York: Criterion Collection, 2013. DVD. 
---, dir. Shoah: Four Sisters. 2018; London: Eureka Entertainment, 2019. DVD.

Larson, Mary A. “"The Medium Is the Message': Oral History, Media, and Mediation," Oral History Review 43, no. 2 (2016): 318-337, doi: 10.1093/ohr/ohw052.

Lee, M. Alexandra. "They Never Looked Back: The Role of the Hakka Women in Jamaica." Caribbean Quarterly 50, no. 2 (2004): 74-80. Accessed December 4, 2018. http://www.jstor.org/stable/40654453.

Lee, Patrick A. Canadian Jamaican Chinese, 2000: A Pictorial History of Jamaican Chinese Families Spanning Five Generations. Scarborough, ON: Huntsmill Graphics Ltd., 2000.

---. Jamaican Chinese Worldwide - One Family. Scarborough, ON: Huntsmill Graphics Ltd., 2004.

Lee, Spike, dir. If God Is Willing and da Creek Don't Rise. 2010; New York: HBO Home Video, 2011. DVD.

---. When the Levees Broke: A Requiem in Four Acts. 2006; New York: HBO Home Video, 2006. DVD.

Lee-Loy, Anne-Marie. Searching for Mr. Chin: Constructions of Nation and the Chinese in West Indian Literature. Philadelphia: Temple University Press, 2010.

---. "Unfinished Synthesis: Georg Simmel's Adventure, Two Chinese Jamaican Migration Narratives, and the Negotiation of Modern Identity." Caribbean Studies 38, no. 1 (2010): 147-167, doi: 10.1353/crb.2010.0026.

Lewis, Lynn. The Picture the Homeless Oral History Project. Accessed May 1, 2019. https://picturethehomelessoralhistoryproject.com.

Liuting, Monica. "Time \& Memory in Exhibit and Installation Work: A Conundrum." Columbia I OHMA: Oral History Master of Arts (blog), July 3, 2017. http://oralhistory.columbia.edu/blog-posts/People/time-memory-in-exhibit-and-installatio n-work-a-conundrum.

Look Lai, Walton. The Chinese in the West Indies, 1806-1995: A Documentary History. Kingston, Jamaica: The Press University of the West Indies, 1998.

Louie B. Nunn Center for Oral History at the University of Kentucky. Haiti Memory Project. 
Accessed March 15, 2019. https://www.haitimemoryproject.org.

Lucas, Martin. "Documentary: Trauma and an Ethics of Knowing." Post Script 36, nos. 2-3 (2017): 98-116. Academic OneFile (accessed November 12, 2018). http://link.galegroup.com.ezproxy.lib.ryerson.ca/apps/doc/A532995704/AONE?u=rpu_m ain\&sid=AONE\&xid=a27c721a.

Maitland, Keith, dir. Tower. 2016; New York: Kino Classics, 2017. DVD.

Mariposa Film Group, dir. Word Is Out: Stories of Some of Our Lives. 1977; New York: Oscilloscope Laboratories, 2010. DVD.

McElwee, Ross, dir. Bright Leaves. 2003; New York: First Run Features, 2005. DVD.

McKirdy, Carol. Practicing Oral History with Immigrant Narrators. New York: Routledge, 2015.

Mejia, Paula. "The Kaleidoscopic Flicker." The Paris Review, May 12, 2017. https://www.theparisreview.org/blog/2017/05/12/the-kaleidoscopic-flicker/

Merriam, Sharan B., Juanita Johnson-Bailey, Ming-Yeh Lee, Youngwha Kee, Gabo Ntseane, and Mazanah Muhamad. "Power and Positionality: Negotiating Insider/Outsider Status Within and Across Cultures." International Journal of Lifelong Education 20, no. 5 (2001): 405-416.

Milach, Rafal, with Svetlana Alexievich. 7 Rooms. Heidelberg: Kehrer Verlag, 2013.

Miller, Elizabeth, Edward Little, and Steven High. Going Public: The Art of Participatory Practice. Vancouver: UBC Press, 2017.

Minh-ha, Trinh T. Surname Viet, Given Name Nam. 1989. Film.

New York Public Library Community Oral History Project, The. The New York Public Library Community Oral History Project. Accessed March 1, 2019. http://oralhistory.nypl.org.

Nguyễn, Jacqueline Hoàng, Vanessa Kwan, and Dan Pon, eds. The Making of an Archive. Vancouver: Grunt Gallery, 2018.

Nichols, Bill. Introduction to Documentary. Third Edition. Bloomington, IN: Indiana University Press, 2017. 
Norkunas, Martha. "The Vulnerable Listener." In Oral History Off the Record: Toward an Ethnography of Practice, edited by Anna Sheftel and Stacey Zembrzycki, 81-96. New York: Palgrave Macmillan, 2013.

Northwestern University. Knight Lab. Accessed March 1, 2019. https://knightlab.northwestern.edu.

Oral History Association. "OHA Principles and Best Practices.” Last modified October 2018. https://www.oralhistory.org/principles-and-best-practices-revised-2018/.

"Our History." The Chinese Caribbean Association. Accessed April 30, 2019. http://caribbeanchinese.ca/Our-History.

Parr, Joy. “'Don't Speak for Me': Practicing Oral History amid the Legacies of Conflict." In The Canadian Oral History Reader, edited by Kristina R. Llewellyn, Alexander Freund, and Nolan Reilly, 335-346. Montreal \& Kingston: McGill-Queen's University Press, 2015.

Paschen, Stephen H. "Archiving Oral History.” In Catching Stories: A Practical Guide to Oral History, edited by Donna M. DeBlasio, Charles F. Ganzert, David H. Mould, Stephen H. Paschen, and Howard L. Sacks, 163-176. Athens, OH: Swallow Press / Ohio University Press, 2009.

Patel, Geeta and Ravi, dir. Meet the Patels. 2014; Los Angeles: Alchemy, 2016. DVD.

"Performing and Visual Arts." The Centre for Oral History and Digital Storytelling at Concordia University. Accessed March 20, 2018. http://storytelling.concordia.ca/research-creation/arts.

Perks, Robert, and Alistair Thomson. "Interviewing." In The Oral History Reader, Third Edition, edited by Robert Perks and Alistair Thomson, 135-146. New York: Routledge, 2016.

Peterson, Jan. L. "The Intersection of Oral History and the Role of White Researchers in Cross-Cultural Contexts." Educational Foundations, 22, no. 3-4 (2008): 33-52. Accessed December 4, 2018. https://files.eric.ed.gov/fulltext/EJ857638.pdf.

Polley, Sarah, dir. Stories We Tell. 2012; Santa Monica, CA: Lionsgate, 2013. DVD.

Queer Newark Oral History Project. Queer Newark Oral History Project. Accessed December 4, 2018. https://queer.newark.rutgers.edu. 
Religion \& Ethics Newsweekly. "Interview: Studs Terkel.” Last modified December 19, 2003. https://www.pbs.org/wnet/religionandethics/2003/12/19/december-19-2003-interview-stu ds-terkel/11022/.

Renov, Michael. "Domestic Ethnography and the Construction of the 'Other' Self." In Collecting Visable Evidence, edited by Michael Renov and Jane M. Gaines, 140-155. Minneapolis: University of Minnesota Press, 1999.

---. "Towards a Poetics of Documentary." In Theorizing Documentary, edited by Michael Renov, 12-36. New York: Routledge, 1993.

---. The Subject of Documentary (Minneapolis: University of Minnesota Press, 2004).

Ritchie, Donald A. Doing Oral History. Third Edition. New York: Oxford University Press, 2015.

Ryan, Kathleen M. "Beyond Thick Dialogue: Oral History and the 'Thickening' of Multimedia Storytelling." Visual Communication Quarterly 22, no. 2 (2015): 85-93, doi:10.1080/15551393.2015.1042160.

Sacco, Joe. Footnotes in Gaza. New York: Metropolitan Books, 2009.

Sacks, Howard L. "Ethics and Politics in Oral History Research." In Catching Stories: A Practical Guide to Oral History, edited by Donna M. DeBlasio, Charles F. Ganzert, David H. Mould, Stephen H. Paschen, and Howard L. Sacks, 42-55. Athens, OH: Swallow Press / Ohio University Press, 2009.

Sandino, Linda. "Introduction: Oral History in and about Art, Craft and Design." In Oral History in the Visual Arts, edited by Linda Sandino and Matthew Partington, 1-13. New York: Bloomsbury Publishing, 2013.

Schneider, William. "Interviewing in Cross-Cultural Settings." In The Oxford Handbook of Oral History, edited by Donald A. Ritchie, 51-64. New York: Oxford University Press, 2012.

Schrum, Kelly, Sheila Brennan, James Halabuk, Sharon M. Leon, and Tom Scheinfeldt. "Oral History in the Digital Age." In The Oxford Handbook of Oral History, edited by Donald A. Ritchie, 499-516. New York: Oxford University Press, 2011. 
Shopes, Linda. "'Insights and Oversights': Reflections on the Documentary Tradition and the Theoretical Turn in Oral History." Oral History Review 41, no. 2 (2014): 257-268, doi: 10.1093/ohr/ohu035.

---. "Oral History and the Study of Communities: Problems, Paradoxes, and Possibilities." The Journal of American History 89, no. 2 (2002): 588-98, doi:10.2307/3092177.

Smith, Anna Deveare. Twilight: Los Angeles, 1992. New York: Anchor Books, 1994.

Smith, Graham. "Toward a Public Oral History." In The Oxford Handbook of Oral History, edited by Donald A. Ritchie, 429-448. New York: Oxford University Press, 2011.

Sommer, Barbara W., and Mary Kay Quinlan. The Oral History Manual. Third Edition. Lanham, MD: Rowman \& Littlefield, 2018.

Stanton, Brandon. Humans of New York. Accessed March 1, 2019. https://www.humansofnewyork.com.

Starecheski, Amy. "Oral History, Community and Displacement: Imagining Memories in Post-Apartheid South Africa," Oral History Review 40, no. 2 (2013): 466-469, https://doi.org/10.1093/ohr/oht074.

StoryCorps. Accessed March 1, 2019. https://storycorps.org.

Terkel, Studs. "The Good War": An Oral History of World War II. New York: Pantheon Books, 1984.

---. Working: People Talk About What They Do All Day and How They Feel About What They Do. New York: Pantheon Books, 1974.

Thomson, Alistair. "Family Photographs and Migrant Memories: Representing Women's Lives." In Oral History and Photography, edited by Alexander Freund and Alistair Thomson, 169-86. New York: Palgrave Macmillan, 2011.

---. "Moving Stories: Oral History and Migration Studies." Oral History 27, no. 4 (1999): 24-37. Accessed March 15, 2019. http://www.jstor.org/stable/40179591.

Thompson, Paul, with Joanna Bornat. The Voice of the Past: Oral History. Fourth Edition. New York: Oxford University Press, 2017. 
Valk, Anne, and Holly Ewald. "Bringing a Hidden Pond to Public Attention: Increasing Impact through Digital Tools," Oral History Review 40, no. 1 (2013): 8-24, doi: 10.1093/ohr/oht019.

Walton, Sarah-Jane. "Historian as Filmmaker: Reflections on the Making of the Film Documentary Those Dying Days." South African Historical Journal 68, no. 4 (2016): 623-640, doi:10.1080/02582473.2016.1214170.

Warner, Michael. Publics and Counterpublics. New York : Zone Books, 2014.

Williams-Wong, Carol. Letters To My Grandchildren: Memoirs of a Dragon Lady - Volume I. Toronto: Resources Supporting Family \& Community Legacies Inc., 2014.

---. Letters To My Grandchildren: Memoirs of a Dragon Lady - Volume II. Toronto: Resources Supporting Family \& Community Legacies Inc., 2014.

Wolozin, Sarah. "The New Digital Storytelling Series: Katerina Cizek." MIT Open Documentary Lab. Accessed May 14, 2019.

https://docubase.mit.edu/lab/interviews/the-new-digital-storytelling-series-katerina-cizek.

Wong, Alan. "Listen and Learn: Familiarity and Feeling in the Oral History Interview." In Oral History Off the Record: Toward an Ethnography of Practice, edited by Anna Sheftel and Stacey Zembrzycki, 97-111. New York: Palgrave Macmillan, 2013.

Yow, Valerie Raleigh. Recording Oral History: A Guide for the Humanities and Social Sciences, Second Edition. Walnut Creek, CA: AltaMira Press, 2005.

Zahavi, Gerald. "Notes from the Field: Digital History and Oral History." In Oral History and Digital Humanities: Voice, Access, and Engagement, edited by Douglas A. Boyd and Mary A. Larson, 119-132 (New York: Palgrave Macmillan, 2014).

Zhangke, Jia, dir. 24 City. 2008; New York: Cinema Guild, 2010. DVD.

Zoller Seitz, Matt. "Shoah: Four Sisters.” RogerEbert.com. Last modified November 14, 2018. https://www.rogerebert.com/reviews/shoah-four-sisters-2018. 